\title{
Use of personal call alarms among community-dwelling older people
}

\section{SAMUEL R. NYMAN*}

* School of Design, Engineering \& Computing, Bournemouth University, United Kingdom

1

Use of personal call alarms among community-dwelling older people

Nyman, S. R., \& Victor,

C.

$\mathrm{R}$.

(2012)

Use

of

pers??????????????????????????????????????????>???????>???????????????????????????????-????????????????????0nal call alarms among community-

dwelling

older

people.

Ageing

$\&$

Society,

Published

online:

15

August,

DOI:

10.1017/S0144686X12000803.

(C)

Cambridge

University

Press

2012.

http://journals.cambridge.org/action/displayAbstract;jsessionid=CECAB498AA3794F4F65BFC3B843D6955.journals?fromPage= 
1

Use of personal call alarms among community-dwelling older people

Nyman, S. R., \& Victor,

C.

$\mathrm{R}$.

(2012).

Use

of

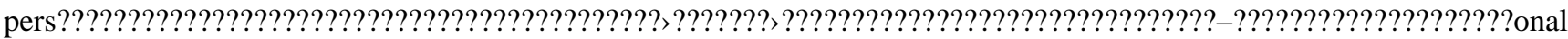

call alarms among community-

dwelling

older

people.

Ageing

\&

Society,

Published

online:

15

August,

DOI:

10.1017/S0144686X12000803.

(C)

Cambridge

University

Press

2012.

http://journals.cambridge.org/action/displayAbstract;jsessionid=CECAB498AA3794F4F65BFC3B843D6955.journals?fromPage=

\section{ABSTRACT}

Having a fall and then lying on the floor for an hour or more is known as a 'long lie', which are associated with serious injury and an elevated risk of admission to hospital, long-term care, and death. Personal call alarms are designed to prevent long lies, although little is known about their use. Using cross-sectional data from the English Longitudinal Study on Ageing, this study investigated the proportion of self-reported users of personal call alarms among 3091 
community-dwelling adults aged 65+ who reported difficulties of mobility or activities of daily living. The characteristics of users were then explored through logistic regressions comparing those living alone with those living with others. One hundred and eighty people selfreported using a personal call alarm $(6 \%)$. Multivariate regression found the following to significantly predict personal call alarm use among both those living alone and with others: greater difficulty with activities / instrumental activities of daily living, older age, and for

1

Use of personal call alarms among community-dwelling older people

Nyman, S. R., \& Victor,

C.

$\mathrm{R}$.

(2012).

Use

of

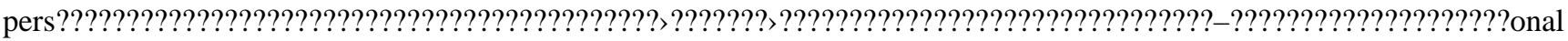
call alarms among community-

dwelling

older

people.

Ageing

\&

Society,

Published

online:

15

August,

DOI:

10.1017/S0144686X12000803.

(C)

Cambridge

University

Press

2012.

http://journals.cambridge.org/action/displayAbstract;jsessionid=CECAB498AA3794F4F65BFC3B843D6955.journals?fromPage= 
1

Use of personal call alarms among community-dwelling older people

Nyman, S. R., \& Victor,

C.

R.

(2012)

Use

of

pers?????????????????????????????????????????>??????+??????????????????????????????-????????????????????onal call alarms among community-

dwelling

older

people.

Ageing

\&

Society,

Published

online:

15

August,

DOI:

10.1017/S0144686X12000803.

(C)

Cambridge

University

Press

2012.

http:/journals.cambridge.org/action/displayAbstract;jsessionid=CECAB498AA3794F4F65BFC3B843D6955.journals?fromPage=

those living with others only: lower score on the quality of life subscale for control. Personal call alarm use may be markedly lower than the 30 per cent annual incidence of falls among community-dwelling older people. Better understanding is needed of the reasons for low usage, even amongst those at highest falls risk for whom such alarms are most likely to be beneficial.

KEY WORDS - Assistive technology; community healthcare; falls, accidental; prevention 


\section{Introduction}

Falls are a major threat to older people's health and independence, with a third of those aged 65+ residing in the community and half of those in institutions experiencing a fall annually (Kannus et al. 2005; Rubenstein 2006; Skelton and Todd 2004). While interventions can reduce the rate and risk of falls in older people (Cameron et al. 2010; Gillespie et al. 2009), a zero falls rate is likely

1

Use of personal call alarms among community-dwelling older people

Nyman, S. R., \& Victor,

C.

$\mathrm{R}$.

(2012).

Use

of

pers?????????????????????????????????????????>???????>??????????????????????????????-???????????????????onal call alarms among community-

dwelling

older

people.

Ageing

\&

Society,

Published

online:

15

August,

DOI:

10.1017/S0144686X12000803.

(C)

Cambridge

University

Press

2012.

http://journals.cambridge.org/action/displayAbstract;jsessionid=CECAB498AA3794F4F65BFC3B843D6955.journals?fromPage= 
1

Use of personal call alarms among community-dwelling older people

Nyman, S. R., \& Victor,

C.

R.

(2012)

Use

of

pers?????????????????????????????????????????>?????????????????????????????????????-????????????????????onal call alarms among community-

dwelling

older

people.

Ageing

\&

Society,

Published

online:

15

August,

DOI:

10.1017/S0144686X12000803.

(C)

Cambridge

University

Press

2012.

http:/journals.cambridge.org/action/displayAbstract;jsessionid=CECAB498AA3794F4F65BFC3B843D6955.journals?fromPage=

not only to be unattainable but also to impinge on human rights of older people in order to achieve it (Nyman and Oliver 2010; Oliver 2004). Therefore, when falls do occur they need to be effectively managed with one element of this being the prompt summonsing of assistance.

Assistive technology includes a range of interventions from simple aids such as walking sticks and frames to sophisticated home-based systems including telecare, which are used to homemanage various health conditions and facilitate the retention of independence (Audit Commission 
2004; Brignell, Wootton and Gray 2007; Brownsell, Aldred and Hawley 2007). Personal call alarms are a form of assistive technology that has been developed to reduce long lies: an older person falling and then lying on the floor for an hour or longer. Long lies are estimated to occur in half of the falls experienced in the community (Tinetti, Liu and Claus 1993), and are associated with serious injuries, admissions to hospitals and care homes (Fleming, Brayne and the Cambridge City over-75s Cohort (CC75C) study collaboration 2008), and an increased risk of

\section{1}

Use of personal call alarms among community-dwelling older people

Nyman, S. R., \& Victor,

C.

R.

(2012).

Use

of

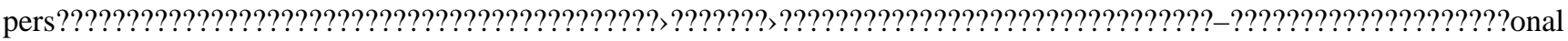
call alarms among community-

dwelling

older

people.

Ageing

$\&$

Society,

Published

online:

15

August,

DOI:

10.1017/S0144686X12000803.

(C)

Cambridge

University

Press

2012.

http://journals.cambridge.org/action/displayAbstract;jsessionid=CECAB498AA3794F4F65BFC3B843D6955.journals?fromPage= 
1

Use of personal call alarms among community-dwelling older people

Nyman, S. R., \& Victor,

C.

R.

(2012).

Use

of

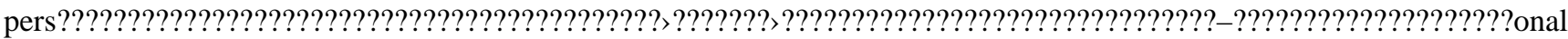
call alarms among community-

dwelling

older

people.

Ageing

\&

Society,

Published

online:

15

August,

DOI:

10.1017/S0144686X12000803.

(C)

Cambridge

University

Press

2012.

http://journals.cambridge.org/action/displayAbstract;jsessionid=CECAB498AA3794F4F65BFC3B843D6955.journals?fromPage=

mortality (Gurley et al. 1996; Wild, Nayak and Isaacs 1981). Personal call alarms are designed to prevent long lies by providing a faller with the facility to release a distress call when lying on the floor. By pressing a button on a device worn on the neck / wrist an emergency response can be solicited from a relative, service centre, or warden if the dwelling is in sheltered housing.

Developments are also being made to automatically detect falls that would negate the need for the user to activate the alarm (e.g. Lee and Carlisle 2011; Leone, Diraco and Siciliano 2011); useful 
for when an older person is confused or left unconscious / disorientated (Brownsell and Hawley 2006; Rajendran et al. 2008). However, automatic fall detectors are rarely used at present and require further development because they are prone to false alarms (Brownsell and Hawley 2004; Noury et al. 2008; Prado-Velasco et al. 2006).

As with the efficacy of assistive technology, information and communication technology (Blaschke, Freddolino and Mullen 2009), and home telecare in general (Martin et al. 2008;

1

Use of personal call alarms among community-dwelling older people

Nyman, S. R., \& Victor,

C.

$\mathrm{R}$.

(2012).

Use

of

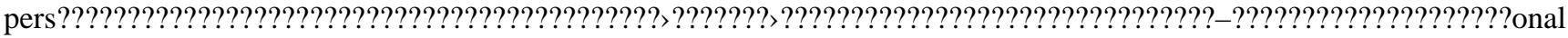
call alarms among community-

dwelling

older

people.

Ageing

\&

Society,

Published

online:

15

August,

DOI:

10.1017/S0144686X12000803.

(C)

Cambridge

University

Press

2012.

http://journals.cambridge.org/action/displayAbstract;jsessionid=CECAB498AA3794F4F65BFC3B843D6955.journals?fromPage= 
1

Use of personal call alarms among community-dwelling older people

Nyman, S. R., \& Victor,

C.

R.

(2012)

Use

of

pers?????????????????????????????????????????>??????+??????????????????????????????-????????????????????onal call alarms among community-

dwelling

older

people.

Ageing

\&

Society,

Published

online:

15

August,

DOI:

10.1017/S0144686X12000803.

(C)

Cambridge

University

Press

2012.

http:/journals.cambridge.org/action/displayAbstract;jsessionid=CECAB498AA3794F4F65BFC3B843D6955.journals?fromPage=

Takahashi et al. 2012), the evidence-base is limited for the efficacy of personal call alarms to improve older people's health and social care (Barlow et al. 2007). In addition, particularly in England as telecare has been incentivised (Department of Health 2009), research is required into the demand for personal call alarms by older people (and by those caring for them) to avoid investment in technology that older people do not find acceptable (Karafyllis 2009). For example, hip protectors appear not only to be ineffective in reducing fall-related fractures (Kiel et al. 2007; 
Parker, Gillespie and Gillespie 2006) but have low acceptability and usage amongst older people (Cameron and Quine 1994; Parker, Gillespie and Gillespie 2005).

An early study suggested a reasonable uptake $(65 \%)$ for personal call alarms among frail older Americans (age not reported) and that 88 per cent held positive attitudes toward them after use (Dibner, Lowy and Morris 1982). Another American study suggested personal call alarms were used on average for 26 months, however, less than half of users (average age $83+/-9$ )

1

Use of personal call alarms among community-dwelling older people

Nyman, S. R., \& Victor,

C.

$\mathrm{R}$

(2012).

Use

of

pers????????????????????????????????????????>???????>?????????????????????????????-???????????????????0nal call alarms among community-

dwelling

older

people.

Ageing

\&

Society,

Published

online:

15

August,

DOI:

10.1017/S0144686X12000803.

(C)

Cambridge

University

Press

2012.

http://journals.cambridge.org/action/displayAbstract;jsessionid=CECAB498AA3794F4F65BFC3B843D6955.journals?fromPage= 
1

Use of personal call alarms among community-dwelling older people

Nyman, S. R., \& Victor,

C.

R.

(2012)

Use

of

pers?????????????????????????????????????????????????+?????????????????????????+????-????????????????????onal call alarms among community-

dwelling

older

people.

Ageing

\&

Society,

Published

online:

15

August,

DOI:

10.1017/S0144686X12000803.

(C)

Cambridge

University

Press

2012.

http:/journals.cambridge.org/action/displayAbstract;jsessionid=CECAB498AA3794F4F65BFC3B843D6955.journals?fromPage=

always wore the device when alone in their home (Levine and Tideiksaar 1995). More recent studies have suggested that usage rates of personal call alarms are low among Americans with disabilities aged 60+ (16\%) (Mann et al. 2005), and community-dwelling people in Flanders aged $70-89$ rarely possessed (3\%) or used them (3\%) (Roelands, Van Oost, Depoorter and Buysse 2002). While a Canadian study found high acceptability for personal call alarms (86 - 94\%) and automatic fall detectors (65 - 79\%) among baby boomers and older adults (average ages of 45-49 
and 70-74 respectively) (Mihailidis et al. 2008), a study in Hong Kong found that although adults aged $65+$ generally perceived personal call alarms to be useful there was low interest in actually using one (Lai et al. 2010).

For the current study we were interested in the use of personal call alarms in England. There is some evidence of demand amongst adults aged 72-82 in England for assistive devices in general (Pain et al. 2007) and personal call alarms in particular: 136 out of 176 sheltered housing

1

Use of personal call alarms among community-dwelling older people

Nyman, S. R., \& Victor,

C.

$\mathrm{R}$.

(2012).

Use

of

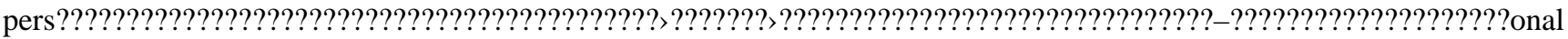
call alarms among community-

dwelling

older

people.

Ageing

\&

Society,

Published

online:

15

August,

DOI:

10.1017/S0144686X12000803.

(C)

Cambridge

University

Press

2012.

http://journals.cambridge.org/action/displayAbstract;jsessionid=CECAB498AA3794F4F65BFC3B843D6955.journals?fromPage= 
1

Use of personal call alarms among community-dwelling older people

Nyman, S. R., \& Victor,

C.

R.

(2012)

Use

of

pers?????????????????????????????????????????????????+?????????????????????????+????-????????????????????onal call alarms among community-

dwelling

older

people.

Ageing

\&

Society,

Published

online:

15

August,

DOI:

10.1017/S0144686X12000803.

(C)

Cambridge

University

Press

2012.

http:/journals.cambridge.org/action/displayAbstract;jsessionid=CECAB498AA3794F4F65BFC3B843D6955.journals?fromPage=

residents (mean age of 76) showed interest in using them (Brownsell et al. 2000), and 31 out of 204 (mean age of 83) who had fallen and not bought assistive technology were paying for a weekly personal call alarm service (Logan et al. 2007). A population-based study in Cambridge also reported that 51 out of 81 nonagenarians in the community or sheltered housing owned a personal call alarm (Fleming, Brayne and the CC75C study collaboration 2008). However, these previous studies are limited in that they recruited specific subgroups of the older population and 
did not recruit from the general population aged 65+ living in the community. In addition, previous studies have recruited small samples prohibiting subgroup analyses to explore the characteristics of users.

A characteristic of particular interest with the use of personal call alarms is household composition. While living alone may not be predictive of use of assistive technology in general (McCreadie and Tinker 2005), it has been suggested that those living alone are more likely to use

1

Use of personal call alarms among community-dwelling older people

Nyman, S. R., \& Victor,

C.

$\mathrm{R}$

(2012).

Use

of

pers????????????????????????????????????????>???????>?????????????????????????????-???????????????????0nal call alarms among community-

dwelling

older

people.

Ageing

\&

Society,

Published

online:

15

August,

DOI:

10.1017/S0144686X12000803.

(C)

Cambridge

University

Press

2012.

http://journals.cambridge.org/action/displayAbstract;jsessionid=CECAB498AA3794F4F65BFC3B843D6955.journals?fromPage= 
1

Use of personal call alarms among community-dwelling older people

Nyman, S. R., \& Victor,

C.

R.

(2012).

Use

of

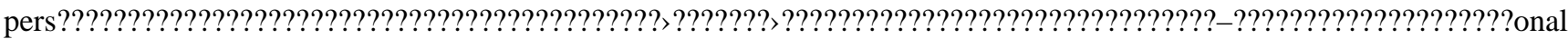
call alarms among community-

dwelling

older

people.

Ageing

\&

Society,

Published

online:

15

August,

DOI:

10.1017/S0144686X12000803.

(C)

Cambridge

University

Press

2012.

http:/journals.cambridge.org/action/displayAbstract;jsessionid=CECAB498AA3794F4F65BFC3B843D6955.journals?fromPage=

a personal call alarm (De San Miguel and Lewin 2008) and be more willing to consider using video monitoring for falls detection in the home (Londei et al. 2009). Older people living alone make greater use of formal care services (Larsson and Thorslund 2002), and may well be under more pressure from health professionals and relatives to use a personal call alarm. Indeed, peace of mind for families has been cited as a reason for using a personal call alarm (Johnston, GrimmerSomers and Sutherland 2010). Thus, the aim of this study was to investigate the proportion of 
users of personal call alarms in a large English sample and explore the characteristics of users. In particular, we wanted to explore whether the characteristics of adults aged 65+ that use personal call alarms differ between those living alone and those living others.

1

Use of personal call alarms among community-dwelling older people

Nyman, S. R., \& Victor,

C.

$\mathrm{R}$

(2012).

Use

of

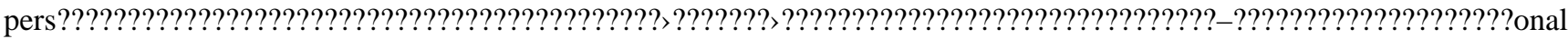
call alarms among community-

dwelling

older

people.

Ageing

\&

Society,

Published

online:

15

August,

DOI:

10.1017/S0144686X12000803.

(C)

Cambridge

University

Press

2012.

http://journals.cambridge.org/action/displayAbstract;jsessionid=CECAB498AA3794F4F65BFC3B843D6955.journals?fromPage= 
1

Use of personal call alarms among community-dwelling older people

Nyman, S. R., \& Victor,

C.

R.

(2012)

Use

of

pers?????????????????????????????????????????>??????+??????????????????????????????-????????????????????onal call alarms among community-

dwelling

older

people.

Ageing

\&

Society,

Published

online:

15

August,

DOI:

10.1017/S0144686X12000803.

(C)

Cambridge

University

Press

2012.

http:/journals.cambridge.org/action/displayAbstract;jsessionid=CECAB498AA3794F4F65BFC3B843D6955.journals?fromPage=

\section{Method}

We conducted a secondary cross-sectional analysis of data from the English Longitudinal Study of Ageing (ELSA) (Marmot et al. 2008). The survey originally recruited participants from the annual government-funded Health Survey for England that used postal codes representative of the general English population (Taylor et al. 2003). While those dwelling in institutions were 
excluded from ELSA and loss of representativeness may have occurred when re-contacting adults (Vlachantoni 2010), the ELSA dataset is widely used and regarded as broadly representative of adults aged 50+ living in private households in England (e.g. Gilleard et al. 2007; Lang et al. 2008; Stafford et al. 2011; Stevens et al. 2008).

We used the third wave (May 2006 - August 2007) of ELSA that recruited 9,771 adults (Taylor et al. 2003), which mainly comprised those aged 54+ who had participated in previous

\section{1}

Use of personal call alarms among community-dwelling older people

Nyman, S. R., \& Victor,

C.

$\mathrm{R}$.

(2012).

Use

of

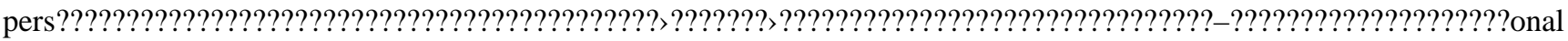
call alarms among community-

dwelling

older

people.

Ageing

\&

Society,

Published

online:

15

August,

DOI:

10.1017/S0144686X12000803.

(C)

Cambridge

University

Press

2012.

http://journals.cambridge.org/action/displayAbstract;jsessionid=CECAB498AA3794F4F65BFC3B843D6955.journals?fromPage= 
1

Use of personal call alarms among community-dwelling older people

Nyman, S. R., \& Victor,

C.

R.

(2012)

Use

of

pers?????????????????????????????????????????>??????+??????????????????????????????-????????????????????onal call alarms among community-

dwelling

older

people.

Ageing

\&

Society,

Published

online:

15

August,

DOI:

10.1017/S0144686X12000803.

(C)

Cambridge

University

Press

2012.

http:/journals.cambridge.org/action/displayAbstract;jsessionid=CECAB498AA3794F4F65BFC3B843D6955.journals?fromPage=

waves $(\mathrm{n}=8,038)$, with an individual response rate of 73 per cent (Marmot and Breeze 2008;

Scholes, Cox and Lessof 2008). From the sample of 4,422 adults aged 65+, 3,091 (70\%) reported difficulty with either mobility, activities of daily living (ADL, e.g. bathing), or instrumental activities of daily living (IADL, e.g. shopping and cooking), and were subsequently asked the question on personal call alarm use that was our dependent variable. In face-to-face structured interviews participants were asked to report if they used any of eight assistive devices, one of 
which was a personal alarm, 'used to call for assistance after falls etc.' (Nunn et al. 2009: 173). The third wave of ELSA was granted ethical approval from the Multicentre Research and Ethics Committee (Nunn et al. 2009: 4) and we registered our study (no. 39558) with the Economic and Social Data Service (www.esds.ac.uk) to obtain permission to access the data file.

Independent variables

Our main independent variable was household composition, which was dichotomised into living

1

Use of personal call alarms among community-dwelling older people

Nyman, S. R., \& Victor,

C.

$\mathrm{R}$.

(2012).

Use

of

pers?????????????????????????????????????????)??????>??????????????????????????????-????????????????????onal call alarms among community-

dwelling

older

people.

Ageing

\&

Society,

Published

online:

15

August,

DOI:

$10.1017 / \mathrm{S} 0144686 \mathrm{X} 12000803$.

(C)

Cambridge

University

Press

2012.

http://journals.cambridge.org/action/displayAbstract;jsessionid=CECAB498AA3794F4F65BFC3B843D6955.journals?fromPage= 
1

Use of personal call alarms among community-dwelling older people

Nyman, S. R., \& Victor,

C.

R.

(2012)

Use

of

pers?????????????????????????????????????????>??????+??????????????????????????????-????????????????????onal call alarms among community-

dwelling

older

people.

Ageing

\&

Society,

Published

online:

15

August,

DOI:

10.1017/S0144686X12000803.

(C)

Cambridge

University

Press

2012.

http:/journals.cambridge.org/action/displayAbstract;jsessionid=CECAB498AA3794F4F65BFC3B843D6955.journals?fromPage=

alone versus living with others (one or more other persons). We then selected 16 further independent variables from factors known to increase the risk of falls: sociodemographics, poor health, and low psychological functioning (Lord et al. 2007; Todd, Ballinger and Whitehead 2007). In addition, we selected variables pertaining to use of communications technology with the assumption that familiarity with this technology may in part predict use of assistive technology.

Sociodemographics. We included age, gender, ethnicity, and socioeconomic status. 
Because ELSA had collapsed the oldest participant ages into 90+, we categorised age into groups of 65-74, 75-84, and 85+. Ethnicity was already collapsed into two options - 'white and nonwhite' - to ensure confidentiality and anonymity of the limited number of participants from minority groups. Wealth was used as a measure of socioeconomic status as conducted with previous waves of ELSA (Stafford, McMunn and de Vogli 2011; Stafford et al. 2011). Wealth has been found to be a more sensitive measure of socioeconomic position in later life, perhaps

1

Use of personal call alarms among community-dwelling older people

Nyman, S. R., \& Victor,

C.

$\mathrm{R}$

(2012).

Use

of

pers?????????????????????????????????????????>??????>?????????????????????????????-???????????????????onal call alarms among community-

dwelling

older

people.

Ageing

$\&$

Society,

Published

online:

15

August,

DOI:

10.1017/S0144686X12000803.

(C)

Cambridge

University

Press

2012.

http://journals.cambridge.org/action/displayAbstract;jsessionid=CECAB498AA3794F4F65BFC3B843D6955.journals?fromPage= 
1

Use of personal call alarms among community-dwelling older people

Nyman, S. R., \& Victor,

C.

R.

(2012).

Use

of

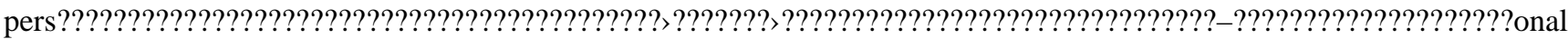
call alarms among community-

dwelling

older

people.

Ageing

\&

Society,

Published

online:

15

August,

DOI:

10.1017/S0144686X12000803.

(C)

Cambridge

University

Press

2012.

http:/journals.cambridge.org/action/displayAbstract;jsessionid=CECAB498AA3794F4F65BFC3B843D6955.journals?fromPage=

because it is more accurate or mediates other indices such as education and occupational class (Marmot and Breeze 2008; Tabassum et al. 2009). A previous measure of wealth was used that summed several items (Tabassum et al. 2009). Items to assess wealth included the value of properties, land, assets, business shares, life assurance, stocks and shares, bonds and gilts, unit and investment trusts, and the amounts held in current and savings accounts.

Health. We included four measures specific to falls and two measures of general health. 
For falls, participants were asked whether they had fallen down in the past two years, and if so, the number of times they had fallen, if any falls resulted in injury that required medical treatment, or if any falls resulted in hip fracture. To avoid small-sample subanalyses, those that reported no falls in the past two years were included in the subsequent variables, i.e. number of falls were $>0$, and those that did not report a fall-related injury or hip fracture included those that had not fallen and those that had fallen but not experienced an injury or fracture. For general health, given that

1

Use of personal call alarms among community-dwelling older people

Nyman, S. R., \& Victor,

C.

$\mathrm{R}$.

(2012).

Use

of

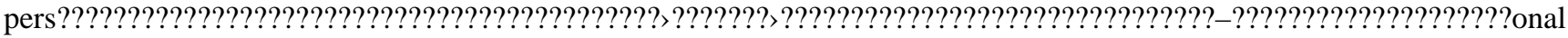
call alarms among community-

dwelling

older

people.

Ageing

\&

Society,

Published

online:

15

August,

DOI:

10.1017/S0144686X12000803.

(C)

Cambridge

University

Press

2012.

http://journals.cambridge.org/action/displayAbstract;jsessionid=CECAB498AA3794F4F65BFC3B843D6955.journals?fromPage= 
1

Use of personal call alarms among community-dwelling older people

Nyman, S. R., \& Victor,

C.

R.

(2012)

Use

of

pers?????????????????????????????????????????>??????+??????????????????????????????-????????????????????onal call alarms among community-

dwelling

older

people.

Ageing

\&

Society,

Published

online:

15

August,

DOI:

10.1017/S0144686X12000803.

(C)

Cambridge

University

Press

2012.

http:/journals.cambridge.org/action/displayAbstract;jsessionid=CECAB498AA3794F4F65BFC3B843D6955.journals?fromPage=

each participant had reported difficulty with either mobility or ADLs / IADLs, all of our sample would report some degree of health problem. We thus created two variables that measured the severity of difficulty with everyday tasks and summed the number of items participants reported difficulty with mobility (range 1-10) and ADL / IADL (range 1-13).

Psychological functioning. We included measures of depression, quality of life, social isolation, and cognitive functioning. Depressive symptoms were measured using the eight-item 
version of the Center for Epidemiologic Studies Depression Scale (CES-D) (Radloff 1977). As defined previously (McMunn et al. 2009), presence of depression was defined as reporting four or more symptoms.

In addition to face-to-face interviews, ELSA participants were asked to self-complete a questionnaire that included the CASP-19 scale, a measure of quality of life derived from a needs satisfaction approach (Hyde et al. 2003). Based on Abraham Maslow's hierarchy of needs, the 19-

1

Use of personal call alarms among community-dwelling older people

Nyman, S. R., \& Victor,

C.

$\mathrm{R}$.

(2012).

Use

of

pers?????????????????????????????????????????)??????>??????????????????????????????-????????????????????onal call alarms among community-

dwelling

older

people.

Ageing

\&

Society,

Published

online:

15

August,

DOI:

10.1017/S0144686X12000803.

(C)

Cambridge

University

Press

2012.

http://journals.cambridge.org/action/displayAbstract;jsessionid=CECAB498AA3794F4F65BFC3B843D6955.journals?fromPage= 
1

Use of personal call alarms among community-dwelling older people

Nyman, S. R., \& Victor,

C.

R.

(2012).

Use

of

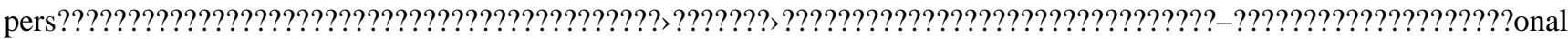

call alarms among community-

dwelling

older

people.

Ageing

\&

Society,

Published

online:

15

August,

DOI:

10.1017/S0144686X12000803.

(C)

Cambridge

University

Press

2012.

http:/journals.cambridge.org/action/displayAbstract;jsessionid=CECAB498AA3794F4F65BFC3B843D6955.journals?fromPage=

item measure comprises four subscales: Control, Autonomy, Self-realisation, and Pleasure.

Control is understood as the ability to influence one's environment; autonomy as freedom from unwanted interference, and self-realisation and pleasure as the active and reflective processes of being human (capturing satisfaction and enjoyment) (Hyde et al. 2003). As intended by the authors, we used the sum score for the total and four subscales. The self-completion questionnaire also included a measure of perceived social isolation, which was measured with one item that 
asked whether participants felt isolated from others (hardly ever or never, some of the time, or often).

Cognitive functioning was assessed through five items pertaining to orientation, registration, fluency, prospective memory, and speed. Orientation was scored on a 4-point scale of whether the correct date was given (correct day of the week, day of the month, month, and year). Registration was the number of words recalled from a list of 10. Fluency was the number of

1

Use of personal call alarms among community-dwelling older people

Nyman, S. R., \& Victor,

C.

R.

(2012).

Use

of

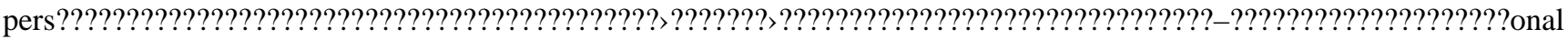
call alarms among community-

dwelling

older

people.

Ageing

\&

Society,

Published

online:

15

August,

DOI:

10.1017/S0144686X12000803.

(C)

Cambridge

University

Press

2012.

http://journals.cambridge.org/action/displayAbstract;jsessionid=CECAB498AA3794F4F65BFC3B843D6955.journals?fromPage= 
1

Use of personal call alarms among community-dwelling older people

Nyman, S. R., \& Victor,

C.

R.

(2012)

Use

of

pers?????????????????????????????????????????>??????+??????????????????????????????-????????????????????onal call alarms among community-

dwelling

older

people.

Ageing

\&

Society,

Published

online:

15

August,

DOI:

10.1017/S0144686X12000803.

(C)

Cambridge

University

Press

2012.

http:/journals.cambridge.org/action/displayAbstract;jsessionid=CECAB498AA3794F4F65BFC3B843D6955.journals?fromPage=

animals freely recalled. Prospective memory was assessed by whether the participant correctly remembered to write their initials at the top left-hand side of a piece of paper when handed to them, but instructed to do so at an earlier time in the assessment. Lastly, speed was the number of letters correctly marked in a letter cancellation task. A composite score for cognitive function was created by categorising participants into low / high functioning for each of the above five tests (1 = incorrect / below median, 2 = correct / above median), and with total possible sum scores of 5 - 
10.

Use of communications technology. The self-completion questionnaire for ELSA contained two further items that we included; whether they currently used the Internet and / or email and owned a mobile phone.

\section{Analysis}

1

Use of personal call alarms among community-dwelling older people

Nyman, S. R., \& Victor,

C.

R.

(2012).

Use

of

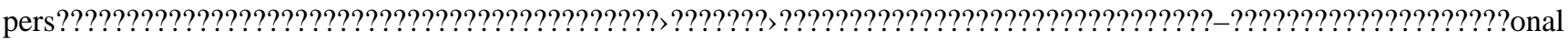
call alarms among community-

dwelling

older

people.

Ageing

\&

Society,

Published

online:

15

August,

DOI:

10.1017/S0144686X12000803.

(C)

Cambridge

University

Press

2012.

http://journals.cambridge.org/action/displayAbstract;jsessionid=CECAB498AA3794F4F65BFC3B843D6955.journals?fromPage= 
1

Use of personal call alarms among community-dwelling older people

Nyman, S. R., \& Victor,

C.

R.

(2012)

Use

of

pers?????????????????????????????????????????>??????+??????????????????????????????-????????????????????onal call alarms among community-

dwelling

older

people.

Ageing

\&

Society,

Published

online:

15

August,

DOI:

10.1017/S0144686X12000803.

(C)

Cambridge

University

Press

2012.

http:/journals.cambridge.org/action/displayAbstract;jsessionid=CECAB498AA3794F4F65BFC3B843D6955.journals?fromPage=

Analyses were conducted using PASW Statistics 18. To check for sampling bias, four multivariate logistic regressions were conducted (enter method of variable entry) separately for sociodemographics, health, psychological functioning, and use of communications technology to test whether there were significant differences between our sample and those that did not report difficulty with mobility or ADL / IADL. Separately for those that reported either living alone or with others, we then computed descriptive statistics on self-reported use of a personal call alarm 
as a function of the aforementioned 16 independent variables, and tested the significance of these variations with bivariate logistic regressions. The independent variables for which these bivariate regressions showed significant (at $\mathrm{p}<0.05$ ) associations with personal call alarm use were then included in a multivariate logistic regression (enter method of variable entry) to calculate adjusted odds ratios, separately for those that reported living alone or with others.

1

Use of personal call alarms among community-dwelling older people

Nyman, S. R., \& Victor,

C.

$\mathrm{R}$.

(2012).

Use

of

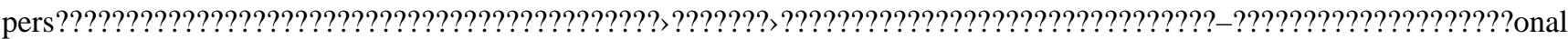
call alarms among community-

dwelling

older

people.

Ageing

$\&$

Society,

Published

online:

15

August,

DOI:

10.1017/S0144686X12000803.

(C)

Cambridge

University

Press

2012.

http://journals.cambridge.org/action/displayAbstract;jsessionid=CECAB498AA3794F4F65BFC3B843D6955.journals?fromPage= 
1

Use of personal call alarms among community-dwelling older people

Nyman, S. R., \& Victor,

C.

R.

(2012)

Use

of

pers?????????????????????????????????????????>?????????????????????????????????????-????????????????????onal call alarms among community-

dwelling

older

people.

Ageing

\&

Society,

Published

online:

15

August,

DOI:

10.1017/S0144686X12000803.

(C)

Cambridge

University

Press

2012.

http:/journals.cambridge.org/action/displayAbstract;jsessionid=CECAB498AA3794F4F65BFC3B843D6955.journals?fromPage=

\section{Results}

From 4,422 respondents aged 65+, 3,091 reported difficulty with mobility or ADL / IADL, and thus were invited to respond to the question for our dependent variable of use of a personal call alarm. In comparing our sample with the 1,331 that did not report difficulty with mobility or ADL / IADL, analyses indicated that our sample was biased on 10 independent variables. Adults aged 
$65+(n=4,422)$ were significantly less likely to report difficulty with mobility or ADL / IADL if they were: younger, male, more wealthy, had not fallen or sustained a fall-related injury in the past two years, did not report depressive symptoms, reported a relatively higher level of quality of life, a relatively higher level of cognitive functioning, used the Internet and / or email, and owned a mobile phone. However, there was no significant difference between participants who did or did not report difficulty with mobility or ADL / IADL as a function of household composition,

1

Use of personal call alarms among community-dwelling older people

Nyman, S. R., \& Victor,

C.

$\mathrm{R}$.

(2012).

Use

of

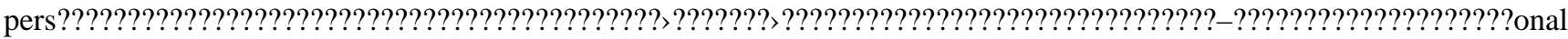
call alarms among community-

dwelling

older

people.

Ageing

\&

Society,

Published

online:

15

August,

DOI:

10.1017/S0144686X12000803.

(C)

Cambridge

University

Press

2012.

http://journals.cambridge.org/action/displayAbstract;jsessionid=CECAB498AA3794F4F65BFC3B843D6955.journals?fromPage= 
1

Use of personal call alarms among community-dwelling older people

Nyman, S. R., \& Victor,

C.

R.

(2012)

Use

of

pers?????????????????????????????????????????>??????+??????????????????????????????-????????????????????onal call alarms among community-

dwelling

older

people.

Ageing

\&

Society,

Published

online:

15

August,

DOI:

10.1017/S0144686X12000803.

(C)

Cambridge

University

Press

2012.

http:/journals.cambridge.org/action/displayAbstract;jsessionid=CECAB498AA3794F4F65BFC3B843D6955.journals?fromPage=

ethnicity, fall-related hip fracture, or perceived social isolation (severity of difficulty with mobility and with ADL / IADL were not analysed given our sample comprised only those that reported problems with these).

Although participants in our sample were biased according to the aforementioned variables, and so were more likely to be fallers and more likely to report using a personal call alarm, our sample for analysis had an age and gender distribution similar to that expected from the 
national population. In particular, our sample bore a close resemblance to the expected percentage distribution for females, but under-represented males aged 65-74 by 7 per cent and overrepresented males aged 75-84 and $85+$ by 4 per cent and 3 per cent respectively (National Statistics 2010a; 2010b).

From our sample of 3,091 adults aged 65+, $180(6 \%)$ self-reported use of a personal call alarm. In a logistic regression, those that reported living alone were significantly more likely to

1

Use of personal call alarms among community-dwelling older people

Nyman, S. R., \& Victor,

C.

$\mathrm{R}$.

(2012).

Use

of

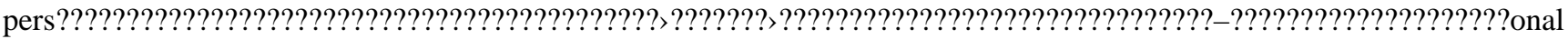
call alarms among community-

dwelling

older

people.

Ageing

\&

Society,

Published

online:

15

August,

DOI:

10.1017/S0144686X12000803.

(C)

Cambridge

University

Press

2012.

http://journals.cambridge.org/action/displayAbstract;jsessionid=CECAB498AA3794F4F65BFC3B843D6955.journals?fromPage= 
1

Use of personal call alarms among community-dwelling older people

Nyman, S. R., \& Victor,

C.

R.

(2012).

Use

of

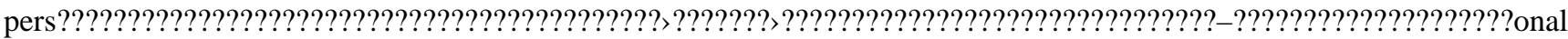
call alarms among community-

dwelling

older

people.

Ageing

\&

Society,

Published

online:

15

August,

DOI:

10.1017/S0144686X12000803.

()

Cambridge

University

Press

2012.

http://journals.cambridge.org/action/displayAbstract;jsessionid=CECAB498AA3794F4F65BFC3B843D6955.journals?fromPage=

report using a personal call alarm (147 of 1,240, 12\%) compared with those that reported living with others $(31$ of $1,822,2 \%)$ (odds ratio $[\mathrm{OR}]=7.77,95 \%$ confidence interval $[\mathrm{CI}]=5.24$ $11.53, p<0.001)$. The descriptive statistics of the sample as a function of self-reported use of a personal call alarm and household composition are presented in Tables 1 and 2 for the categorical and continuous variables respectively. As there was missing data in 29 cases for household composition, the inferential statistics reported below were from a total sample of 3,062 adults 
aged $65+$.

$<$ Insert Tables 1 and 2 about here >

Sociodemographics

Compared to those aged 65-74, adults aged $85+$ were significantly more likely to report use of

1

Use of personal call alarms among community-dwelling older people

Nyman, S. R., \& Victor,

C.

R.

(2012).

Use

of

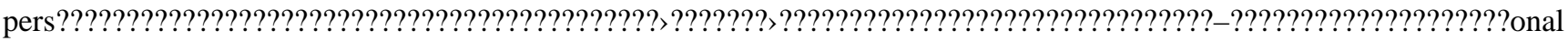
call alarms among community-

dwelling

older

people.

Ageing

\&

Society,

Published

online:

15

August,

DOI:

10.1017/S0144686X12000803.

(C)

Cambridge

University

Press

2012.

http://journals.cambridge.org/action/displayAbstract;jsessionid=CECAB498AA3794F4F65BFC3B843D6955.journals?fromPage= 
1

Use of personal call alarms among community-dwelling older people

Nyman, S. R., \& Victor,

C.

R.

(2012)

Use

of

pers?????????????????????????????????????????>??????+??????????????????????????????-????????????????????onal call alarms among community-

dwelling

older

people.

Ageing

\&

Society,

Published

online:

15

August,

DOI:

10.1017/S0144686X12000803.

(C)

Cambridge

University

Press

2012.

http:/journals.cambridge.org/action/displayAbstract;jsessionid=CECAB498AA3794F4F65BFC3B843D6955.journals?fromPage=

personal call alarms whether living alone or with others. However, only those aged 75-84 and living alone were also significantly more likely to use personal call alarms compared to respondents aged 65-74. There was no significant difference in self-reported use of personal call alarms as a function of gender. We had planned to conduct a bivariate regression of personal call alarm use as a function of ethnicity, however, only 63 participants represented non-white ethnic groups. Consequently, the expected frequency was too low for those that reported living with 
others and using a personal call alarm, which violated the assumption of logistic regression that no more than 20 per cent of cells have an expected frequency below 5 (Field 2009: p. 274). The comparable assumption was violated when we attempted to input wealth as a continuous variable due a highly non-normal distribution (leptokurtic) (Field 2009). However, wealth could be included in the model once collapsed into tertiles. Compared to those in the highest wealth tertile, those living alone and living with others in the lowest wealth tertile were significantly more likely

\section{1}

Use of personal call alarms among community-dwelling older people

Nyman, S. R., \& Victor,

C.

$\mathrm{R}$.

(2012).

Use

of

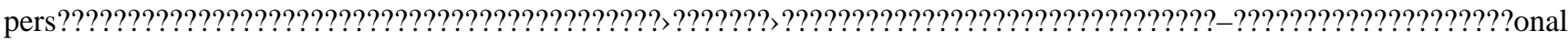
call alarms among community-

dwelling

older

people.

Ageing

$\&$

Society,

Published

online:

15

August,

DOI:

10.1017/S0144686X12000803.

(C)

Cambridge

University

Press

2012.

http://journals.cambridge.org/action/displayAbstract;jsessionid=CECAB498AA3794F4F65BFC3B843D6955.journals?fromPage= 
1

Use of personal call alarms among community-dwelling older people

Nyman, S. R., \& Victor,

C.

R.

(2012)

Use

of

pers?????????????????????????????????????????>?????????????????????????????????????-????????????????????onal

call alarms among community-

dwelling

older

people.

Ageing

\&

Society,

Published

online:

15

August,

DOI:

10.1017/S0144686X12000803.

(C)

Cambridge

University

Press

2012.

http:/journals.cambridge.org/action/displayAbstract;jsessionid=CECAB498AA3794F4F65BFC3B843D6955.journals?fromPage=

to self-report use of a personal call alarm. There was no significant difference between the middle and highest wealth tertiles.

\section{Health}

Participants who reported experiencing a fall in the past two years were significantly more likely to self-report personal call alarm use, but only for those that were living alone. There was no 
significant difference according to the number of falls experienced. Unfortunately, the variables of fall-related injury and fall-related hip fracture could not be analysed because the expected frequencies were too low for those that reported living with others and using a personal call alarm (Field 2009: p. 274). Older people living alone and with others who reported greater difficulty with mobility were significantly more likely to self-report using a personal call alarm, as were those who reported greater difficulty with ADL / IADL.

1

Use of personal call alarms among community-dwelling older people

Nyman, S. R., \& Victor,

C.

$\mathrm{R}$.

(2012).

Use

of

pers???????????????????????????????????????????????+?????????????????????????????-???????????????????+0nal call alarms among community-

dwelling

older

people.

Ageing

\&

Society,

Published

online:

15

August,

DOI:

10.1017/S0144686X12000803.

(C)

Cambridge

University

Press

2012.

http://journals.cambridge.org/action/displayAbstract;jsessionid=CECAB498AA3794F4F65BFC3B843D6955.journals?fromPage= 
1

Use of personal call alarms among community-dwelling older people

Nyman, S. R., \& Victor,

C.

R.

(2012)

Use

of

pers?????????????????????????????????????????>?????????????????????????????????????-????????????????????onal call alarms among community-

dwelling

older

people.

Ageing

\&

Society,

Published

online:

15

August,

DOI:

10.1017/S0144686X12000803.

(C)

Cambridge

University

Press

2012.

http:/journals.cambridge.org/action/displayAbstract;jsessionid=CECAB498AA3794F4F65BFC3B843D6955.journals?fromPage=

\section{Psychological functioning}

Unfortunately, depressive symptoms could not be analysed because the expected frequency was too low for those that reported living with others and using a personal call alarm (Field 2009: p. 274). For both those living alone and with others, those that scored a lower level of cognitive function were significantly more likely to self-report using a personal call alarm, as were those that reported a lower level of quality of life. For the quality of life subscales, three out of four 
were significant for both those living alone and with others, in that personal call alarm users were more likely to report lower scores for control, autonomy, and self-realisation (pleasure was not significant). For those living alone, there was no significant difference in self-reported use of a personal call alarm as a function of perceived isolation. However, for those living with others, compared to those that felt isolated hardly ever or never, those that reported feeling isolated some of the time were significantly more likely to self-report using a personal call alarm (but not those

\section{1}

Use of personal call alarms among community-dwelling older people

Nyman, S. R., \& Victor,

C.

R.

(2012).

Use

of

pers?????????????????????????????????????????>???????+????????????????????????+????-????????????????????onal call alarms among community-

dwelling

older

people.

Ageing

\&

Society,

Published

online:

15

August,

DOI:

10.1017/S0144686X12000803.

(C)

Cambridge

University

Press

2012.

http://journals.cambridge.org/action/displayAbstract;jsessionid=CECAB498AA3794F4F65BFC3B843D6955.journals?fromPage= 
1

Use of personal call alarms among community-dwelling older people

Nyman, S. R., \& Victor,

C.

R.

(2012)

Use

of

pers?????????????????????????????????????????>??????+??????????????????????????????-????????????????????onal call alarms among community-

dwelling

older

people.

Ageing

\&

Society,

Published

online:

15

August,

DOI:

10.1017/S0144686X12000803.

(C)

Cambridge

University

Press

2012.

http:/journals.cambridge.org/action/displayAbstract;jsessionid=CECAB498AA3794F4F65BFC3B843D6955.journals?fromPage=

that reported feeling isolated often).

Use of communications technology

For those living alone, those who reported that they did not use the Internet and / or email were significantly more likely to self-report using a personal call alarm, as were those that reported that they did not own a mobile phone. However, both variables were not significant for those living 
with others.

Multivariate analysis

We entered the significant variables from the above bivariate tests into a multivariate logistic regression to predict self-reported use of a personal call alarm as a function of household composition (see Table 3). For both those living alone and with others, those that reported greater

1

Use of personal call alarms among community-dwelling older people

Nyman, S. R., \& Victor,

C.

$\mathrm{R}$

(2012).

Use

of

pers????????????????????????????????????????>???????>?????????????????????????????-???????????????????0nal call alarms among community-

dwelling

older

people.

Ageing

\&

Society,

Published

online:

15

August,

DOI:

$10.1017 / \mathrm{S} 0144686 \mathrm{X} 12000803$.

(C)

Cambridge

University

Press

2012.

http://journals.cambridge.org/action/displayAbstract;jsessionid=CECAB498AA3794F4F65BFC3B843D6955.journals?fromPage= 
1

Use of personal call alarms among community-dwelling older people

Nyman, S. R., \& Victor,

C.

R.

(2012)

Use

of

pers?????????????????????????????????????????>??????+??????????????????????????????-????????????????????onal call alarms among community-

dwelling

older

people.

Ageing

\&

Society,

Published

online:

15

August,

DOI:

10.1017/S0144686X12000803.

(C)

Cambridge

University

Press

2012.

http:/journals.cambridge.org/action/displayAbstract;jsessionid=CECAB498AA3794F4F65BFC3B843D6955.journals?fromPage=

difficulty with ADL / IADL were significantly more likely to self-report using a personal call alarm. Another variable and one with the highest odds ratios was age, but the predictors differed according to household composition. For those living alone, aged 85+ (vs. 65) was significantly predictive of self-reported personal call alarm use, whereas for those living with others, aged 7584 (vs. 65-74) was significantly predictive. An additional significant variable for those living with others was the quality of life subscale for control, in that those with lower levels of control were 
significantly more likely to self-report using a personal call alarm. For those living with others, those that reported low (vs. high) wealth were marginally but not significantly more likely to selfreport using a personal call alarm $(p=0.058)$. When the multivariate logistic regressions were repeated using the total CASP-19 sum score in place of the three subscales, the total measure of quality of life was not significant.

1

Use of personal call alarms among community-dwelling older people

Nyman, S. R., \& Victor,

C.

$\mathrm{R}$.

(2012).

Use

of

pers????????????????????????????????????????>???????>?????????????????????????????-???????????????????0nal call alarms among community-

dwelling

older

people.

Ageing

\&

Society,

Published

online:

15

August,

DOI:

10.1017/S0144686X12000803.

(C)

Cambridge

University

Press

2012.

http://journals.cambridge.org/action/displayAbstract;jsessionid=CECAB498AA3794F4F65BFC3B843D6955.journals?fromPage= 
1

Use of personal call alarms among community-dwelling older people

Nyman, S. R., \& Victor,

C.

R.

(2012)

Use

of

pers?????????????????????????????????????????>?????????????????????????????????????-????????????????????onal call alarms among community-

dwelling

older

people.

Ageing

\&

Society,

Published

online:

15

August,

DOI:

10.1017/S0144686X12000803.

(C)

Cambridge

University

Press

2012.

http://journals.cambridge.org/action/displayAbstract;jsessionid=CECAB498AA3794F4F65BFC3B843D6955.journals?fromPage=

< Insert Table 3 about here >

\section{Discussion}

Using cross-sectional data from the English Longitudinal Study on Ageing, we investigated the proportion of users of personal call alarms and explored the characteristics of these users. 
Building on prior research that recruited small samples of subgroups of the older population, this study made use of a large English sample from the general population of adults aged 65+ living in the community. Given the more substantial sample size, our study adds to the literature by reporting that only 6 per cent of 3091 adults aged 65+ self-reported using a personal call alarm, and that usage was much higher among those living alone than with others (12\% vs. $2 \%$ ). Previous studies that solicited older people for their opinion on personal call alarms have found

1

Use of personal call alarms among community-dwelling older people

Nyman, S. R., \& Victor,

C.

$\mathrm{R}$.

(2012).

Use

of

pers???????????????????????????????????????>??????>????????????????????????????-???????????????????+onal call alarms among community-

dwelling

older

people.

Ageing

\&

Society,

Published

online:

15

August,

DOI:

10.1017/S0144686X12000803.

(C)

Cambridge

University

Press

2012.

http://journals.cambridge.org/action/displayAbstract;jsessionid=CECAB498AA3794F4F65BFC3B843D6955.journals?fromPage= 
1

Use of personal call alarms among community-dwelling older people

Nyman, S. R., \& Victor,

C.

R.

(2012).

Use

of

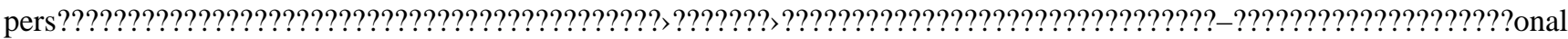

call alarms among community-

dwelling

older

people.

Ageing

\&

Society,

Published

online:

15

August,

DOI:

10.1017/S0144686X12000803.

(C)

Cambridge

University

Press

2012.

http://journals.cambridge.org/action/displayAbstract;jsessionid=CECAB498AA3794F4F65BFC3B843D6955.journals?fromPage=

high rates for acceptance (65 - 94\%) (Brownsell et al. 2000; Dibner, Lowy and Morris 1982; Mihailidis et al. 2008) and positive attitudes toward them after use (88\%) (Dibner, Lowy, and Morris 1982). However, our results are similar to previous studies that recruited older people from the community and sheltered housing that reported low rates for use of personal call alarms in terms of possession (3 - 15\%) (Logan et al. 2007; Roelands, Van Oost, Depoorter and Buysse 2002), and use (3\%) (Roelands, Van Oost, Depoorter and Buysse 2002), including use among 
those with disabilities (16\%) (Mann et al. 2005). Personal call alarms may be used to a much lesser extent than other assistive devices, as older people's adherence to prescribed assistive technology for mobility, bathing, and dressing, etc. has been reported to lie in the range of 35 to 87 per cent (Steel and Gray 2009).

Thus, it appears that personal call alarms are highly accepted but rarely used, which resonates with the results of a survey conducted in Hong Kong (Lai et al. 2010), and an earlier

1

Use of personal call alarms among community-dwelling older people

Nyman, S. R., \& Victor,

C.

$\mathrm{R}$.

(2012).

Use

of

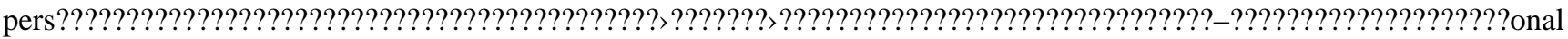
call alarms among community-

dwelling

older

people.

Ageing

\&

Society,

Published

online:

15

August,

DOI:

10.1017/S0144686X12000803.

(C)

Cambridge

University

Press

2012.

http://journals.cambridge.org/action/displayAbstract;jsessionid=CECAB498AA3794F4F65BFC3B843D6955.journals?fromPage= 
1

Use of personal call alarms among community-dwelling older people

Nyman, S. R., \& Victor,

C.

R.

(2012)

Use

of

pers?????????????????????????????????????????????????+?????????????????????????+????-????????????????????onal call alarms among community-

dwelling

older

people.

Ageing

\&

Society,

Published

online:

15

August,

DOI:

10.1017/S0144686X12000803.

(C)

Cambridge

University

Press

2012.

http:/journals.cambridge.org/action/displayAbstract;jsessionid=CECAB498AA3794F4F65BFC3B843D6955.journals?fromPage=

finding that older people perceive falls prevention interventions to be helpful in general but not relevant for them personally due to a low perceived risk of falls (Braun 1998; Yardley et al. 2006). As our finding of low personal call alarm use relates to previous studies conducted in Flanders (Roelands, Van Oost, Depoorter and Buysse 2002), America (Levine and Tideiksaar 1995; Mann et al. 2005), and Hong Kong (Lai et al. 2010), we suggest that it may apply to community-dwelling older people in other countries. However, findings from a population-based 
sample of the 'oldest old' in Cambridge (United Kingdom) found the proportion of very old people with personal call alarms ( $63 \%$ of $>90$-year-olds not in long-term care) was much higher than we found in even our oldest age-band of 85+ (20\%) (Fleming, Brayne and the CC75C study collaboration 2008). Further research could explore this discrepancy in findings and investigate whether there are significant geographical differences in provision and uptake of personal call alarms.

1

Use of personal call alarms among community-dwelling older people

Nyman, S. R., \& Victor,

C.

$\mathrm{R}$.

(2012).

Use

of

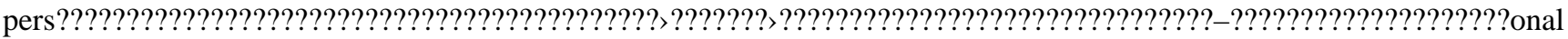
call alarms among community-

dwelling

older

people.

Ageing

\&

Society,

Published

online:

15

August,

DOI:

10.1017/S0144686X12000803.

(C)

Cambridge

University

Press

2012.

http://journals.cambridge.org/action/displayAbstract;jsessionid=CECAB498AA3794F4F65BFC3B843D6955.journals?fromPage= 
1

Use of personal call alarms among community-dwelling older people

Nyman, S. R., \& Victor,

C.

R.

(2012)

Use

of

pers?????????????????????????????????????????>?????????????????????????????????????-????????????????????onal call alarms among community-

dwelling

older

people.

Ageing

\&

Society,

Published

online:

15

August,

DOI:

10.1017/S0144686X12000803.

(C)

Cambridge

University

Press

2012.

http:/journals.cambridge.org/action/displayAbstract;jsessionid=CECAB498AA3794F4F65BFC3B843D6955.journals?fromPage=

Building on prior research that was prohibited in exploring subgroup analyses due to small sample sizes, this study explored the characteristics of users of personal call alarms who were either living alone or with others. Our study adds to the literature in finding that for those living alone, 12 of the 16 independent variables entered were significant at the bivariate level (five items were from the quality of life total and four subscales), and similarly for those living with others, 10 of the 16 independent variables entered were significant at the bivariate level. However, in the 
multivariate analyses, the adjusted odds ratios were all reduced and only two variables remained significant for those living alone and three for those living with others. This suggests that the independent variables were mediated by the variables found significant at the multivariate level. The predictor variables significant at the multivariate level for both those living alone and with others were severity of difficulty with ADL / IADL and age, and for those living with others only, the quality of life subscale for control.

1

Use of personal call alarms among community-dwelling older people

Nyman, S. R., \& Victor,

C.

$\mathrm{R}$

(2012).

Use

of

pers?????????????????????????????????????????>???????>??????????????????????????????-???????????????????onal call alarms among community-

dwelling

older

people.

Ageing

$\&$

Society,

Published

online:

15

August,

DOI:

10.1017/S0144686X12000803.

(C)

Cambridge

University

Press

2012.

http://journals.cambridge.org/action/displayAbstract;jsessionid=CECAB498AA3794F4F65BFC3B843D6955.journals?fromPage= 
1

Use of personal call alarms among community-dwelling older people

Nyman, S. R., \& Victor,

C.

R.

(2012)

Use

of

pers?????????????????????????????????????????>?????????????????????????????????????-????????????????????onal call alarms among community-

dwelling

older

people.

Ageing

\&

Society,

Published

online:

15

August,

DOI:

10.1017/S0144686X12000803.

(C)

Cambridge

University

Press

2012.

http:/journals.cambridge.org/action/displayAbstract;jsessionid=CECAB498AA3794F4F65BFC3B843D6955.journals?fromPage=

For both those living at home and with others, severity of difficulty with ADL / IADL was the only health variable that remained significant at the multivariate level. Our finding that those who reported greater difficulty with ADL / IADL were more likely to self-report using a personal call alarm is consistent with prior studies that have found the presence of long-standing illnesses to increase the risk of falls (Tinetti, Williams and Mayewski 1986); use of assistive mobility devices to predict use of personal call alarms (Levine and Tideiksaar 1995); and lower body 
disability and obesity (Pressler and Ferraro 2010) and severity of disability (McCreadie and Tinker 2005) to predict use of assistive devices.

For both those living at home and with others, age was the only sociodemographic variable that remained significant at the multivariate level. For those living alone, those aged $85+$ were more likely to self-report using a personal call alarm. Use of personal call alarms would be expected to be linked with older age - and more so among those aged 85+ - as falls are more

1

Use of personal call alarms among community-dwelling older people

Nyman, S. R., \& Victor,

C.

$\mathrm{R}$.

(2012).

Use

of

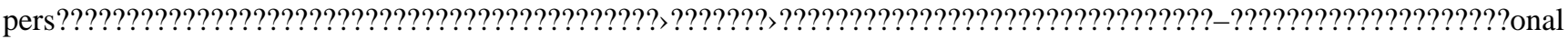
call alarms among community-

dwelling

older

people.

Ageing

\&

Society,

Published

online:

15

August,

DOI:

10.1017/S0144686X12000803.

(C)

Cambridge

University

Press

2012.

http://journals.cambridge.org/action/displayAbstract;jsessionid=CECAB498AA3794F4F65BFC3B843D6955.journals?fromPage= 
1

Use of personal call alarms among community-dwelling older people

Nyman, S. R., \& Victor,

C.

R.

(2012).

Use

of

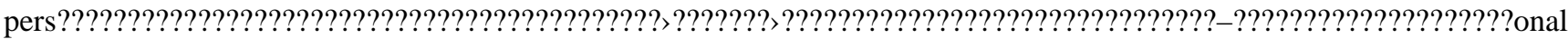

call alarms among community-

dwelling

older

people.

Ageing

\&

Society,

Published

online:

15

August,

DOI:

10.1017/S0144686X12000803.

()

Cambridge

University

Press

2012.

http:/journals.cambridge.org/action/displayAbstract;jsessionid=CECAB498AA3794F4F65BFC3B843D6955.journals?fromPage=

frequent as age advances (Fleming, Matthews, et al. 2008; Skelton and Todd 2004). Personal call alarm use has previously been predicted by being aged 80+ (De San Miguel and Lewin 2008), and use of assistive devices predicted by advanced age (McCreadie and Tinker 2005; Pressler and Ferraro 2010). However, for those living with others, those aged 75-84 were more likely to selfreport using a personal call alarm. This result does not follow the expected trend of increasing frailty - and therefore need for a personal call alarm - with advancing age. Nor can it be explained 
by the other variables controlled for in this study such as wealth, cognitive functioning, and difficulty with mobility. It is thus a finding that could be explored in future studies: it may be that older people living alone have care needs that go unnoticed for many years whereas those living with others have them identified much earlier. It may also represent a survival effect given that 70 per cent of our sample aged 85+ was living alone. Wealth was marginally not significant for those living with others and so would be a further variable to explore in future studies.

1

Use of personal call alarms among community-dwelling older people

Nyman, S. R., \& Victor,

C.

R.

(2012).

Use

of

pers?????????????????????????????????????????>???????>??????????????????????????????-???????????????????onal call alarms among community-

dwelling

older

people.

Ageing

$\&$

Society,

Published

online:

15

August,

DOI:

10.1017/S0144686X12000803.

(C)

Cambridge

University

Press

2012.

http://journals.cambridge.org/action/displayAbstract;jsessionid=CECAB498AA3794F4F65BFC3B843D6955.journals?fromPage= 
1

Use of personal call alarms among community-dwelling older people

Nyman, S. R., \& Victor,

C.

R.

(2012)

Use

of

pers?????????????????????????????????????????>?????????????????????????????????????-????????????????????onal call alarms among community-

dwelling

older

people.

Ageing

\&

Society,

Published

online:

15

August,

DOI:

10.1017/S0144686X12000803.

(C)

Cambridge

University

Press

2012.

http:/journals.cambridge.org/action/displayAbstract;jsessionid=CECAB498AA3794F4F65BFC3B843D6955.journals?fromPage=

From the remaining variables pertaining to psychological functioning and use of communications technology, the only further variable that was significant at the multivariate level was the quality of life subscale for control for those living with others. Control refers to the ability to influence one's environment (Hyde et al. 2003), and those with lower levels of control and living with others were significantly more likely to self-report using a personal call alarm. As control was significant in addition to severity of difficulty with ADL / IADL, this finding supports 
the notion that older people have a felt (subjective) need as well as assessed (objective) need for assistive technology (Tinker and Lansley 2005; Wielandt and Strong 2000). In the current study, control serves as a subjective need and difficulty with ADL / IADL an objective need for a personal call alarm. In the literature, quality of life has been used as an outcome rather than as a predictor variable, e.g. in showing lower levels of quality of life are reported by those with functional limitations (Blane, Netuveli and Montgomery 2008) and higher levels are reported by

\section{1}

Use of personal call alarms among community-dwelling older people

Nyman, S. R., \& Victor,

C.

$\mathrm{R}$

(2012).

Use

of

pers????????????????????????????????????????>???????>?????????????????????????????-???????????????????0nal call alarms among community-

dwelling

older

people.

Ageing

$\&$

Society,

Published

online:

15

August,

DOI:

10.1017/S0144686X12000803.

(C)

Cambridge

University

Press

2012.

http://journals.cambridge.org/action/displayAbstract;jsessionid=CECAB498AA3794F4F65BFC3B843D6955.journals?fromPage= 
1

Use of personal call alarms among community-dwelling older people

Nyman, S. R., \& Victor,

C.

R.

(2012)

Use

of

pers?????????????????????????????????????????>?????????????????????????????????????-????????????????????onal call alarms among community-

dwelling

older

people.

Ageing

\&

Society,

Published

online:

15

August,

DOI:

10.1017/S0144686X12000803.

(C)

Cambridge

University

Press

2012.

http:/journals.cambridge.org/action/displayAbstract;jsessionid=CECAB498AA3794F4F65BFC3B843D6955.journals?fromPage=

those that use assistive technology (Matlabi, Parker and McKee 2011). In relation to falls, lower levels of quality of life have been associated with both falls risk factors (balance, functional mobility, muscle strength, and fear of falling) (Ozcan et al. 2005) and experiencing a fall (Hartholt et al. 2011). As noted above with age, control could be explored in depth in future research to examine why it was only significant for those living with others, and for example whether this reflects better identification of care needs or a survival effect. 


\section{Limitations and suggestions for future research}

We report a study that has made effective use of existing data, though by design, our secondary data analysis was limited in that the data set used was not originally collected for the purpose of our study (Victor 2002). The ELSA survey did not include further information that would have been of interest for our analysis, which further research could explore. Information on how often personal call alarms are worn or activated would be useful, which is unlikely to be often given the

1

Use of personal call alarms among community-dwelling older people

Nyman, S. R., \& Victor,

C.

$\mathrm{R}$

(2012).

Use

of

pers?????????????????????????????????????????>???????>??????????????????????????????-???????????????????onal call alarms among community-

dwelling

older

people.

Ageing

\&

Society,

Published

online:

15

August,

DOI:

10.1017/S0144686X12000803.

(C)

Cambridge

University

Press

2012.

http://journals.cambridge.org/action/displayAbstract;jsessionid=CECAB498AA3794F4F65BFC3B843D6955.journals?fromPage= 
1

Use of personal call alarms among community-dwelling older people

Nyman, S. R., \& Victor,

C.

R.

(2012).

Use

of

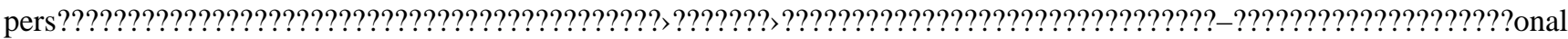
call alarms among community-

dwelling

older

people.

Ageing

\&

Society,

Published

online:

15

August,

DOI:

10.1017/S0144686X12000803.

()

Cambridge

University

Press

2012.

http:/journals.cambridge.org/action/displayAbstract;jsessionid=CECAB498AA3794F4F65BFC3B843D6955.journals?fromPage=

findings from previous studies (Fleming, Brayne and the CC75C study collaboration 2008; Levine and Tideiksaar 1995), though an Australian study reported high use around the home and in the garden (De San Miguel and Lewin 2008). Fear of falling is another variable of interest, as concern with falling has been found to predict personal call alarm use (Mann et al. 2005). Though, while it has been reported that personal call alarm use can reduce fear of falls and increase perceived confidence and security (De San Miguel and Lewin 2008; Mann et al. 2005), results from a 
randomised controlled trial do not support this conclusion (Lee et al. 2007).

Further research could build on our findings and explore further why older people rarely use personal call alarms. Low usage of assistive technology may be because of either lack of awareness of such technology and training in its use among older people; lack of involvement of older people in its development (Selwyn 2004; Selwyn et al. 2003); or both (Charness and Czaja 2005). In regard to awareness, a study in Belgium suggested that older people were more likely to

1

Use of personal call alarms among community-dwelling older people

Nyman, S. R., \& Victor,

C.

$\mathrm{R}$

(2012).

Use

of

pers?????????????????????????????????????????>???????>?????????????????????????????-???????????????????onal call alarms among community-

dwelling

older

people.

Ageing

\&

Society,

Published

online:

15

August,

DOI:

10.1017/S0144686X12000803.

(C)

Cambridge

University

Press

2012.

http://journals.cambridge.org/action/displayAbstract;jsessionid=CECAB498AA3794F4F65BFC3B843D6955.journals?fromPage= 
1

Use of personal call alarms among community-dwelling older people

Nyman, S. R., \& Victor,

C.

R.

(2012)

Use

of

pers?????????????????????????????????????????>?????????????????????????????????????-????????????????????onal call alarms among community-

dwelling

older

people.

Ageing

\&

Society,

Published

online:

15

August,

DOI:

10.1017/S0144686X12000803.

(C)

Cambridge

University

Press

2012.

http:/journals.cambridge.org/action/displayAbstract;jsessionid=CECAB498AA3794F4F65BFC3B843D6955.journals?fromPage=

choose not to use a personal alarm system than be unaware of them (60\% vs. 25\%) (Roelands, Van Oost, Buysse and Depoorter 2002). In regard to involving older people in the design of personal call alarms, future research could determine whether low usage is more determined by a) lack of felt need or b) lack of acceptability of the device (McCreadie and Tinker 2005). Resistance to using personal call alarms has been reported in frail older women despite a perceived risk of long lies (Porter and Ganong 2002). Thus, low use may be due to older people protecting their self- 
identity (Johnston, Grimmer-Somers and Sutherland 2010), in that using a personal call alarm may be perceived as a symbol of frailty and dependency as noted with fall detectors, bed occupancy sensors, and other assistive devices (Gitlin, Luborsky, and Schemm 1998; Horton 2008). Control has also been noted as a barrier to using automatic falls detectors because of older people's fear of the device activating false alerts (Brownsell and Hawley 2004; Fleming, Brayne and the CC75C study collaboration 2008), and so the manual activation of alerts using personal

1

Use of personal call alarms among community-dwelling older people

Nyman, S. R., \& Victor,

C.

$\mathrm{R}$

(2012).

Use

of

pers?????????????????????????????????????????>??????>?????????????????????????????-???????????????????onal call alarms among community-

dwelling

older

people.

Ageing

\&

Society,

Published

online:

15

August,

DOI:

10.1017/S0144686X12000803.

(C)

Cambridge

University

Press

2012.

http://journals.cambridge.org/action/displayAbstract;jsessionid=CECAB498AA3794F4F65BFC3B843D6955.journals?fromPage= 
1

Use of personal call alarms among community-dwelling older people

Nyman, S. R., \& Victor,

C.

R.

(2012)

Use

of

pers?????????????????????????????????????????>?????????????????????????????????????-????????????????????onal call alarms among community-

dwelling

older

people.

Ageing

\&

Society,

Published

online:

15

August,

DOI:

10.1017/S0144686X12000803.

(C)

Cambridge

University

Press

2012.

http:/journals.cambridge.org/action/displayAbstract;jsessionid=CECAB498AA3794F4F65BFC3B843D6955.journals?fromPage=

call alarms were preferred (Horton 2008).

Implications for policy and practice

From a large sample of community-dwelling adults aged 65+ in England, our study indicates that self-reported use of personal call alarms is rare. While such technology may not be appropriate for 
all older people dwelling in the community, it appears that among this group there is inadequate prevention of long lie-related serious injury and consequent hospital treatment, care home admission, or fatality (Fleming, Brayne and the CC75C study collaboration 2008; Gurley et al. 1996; Wild, Nayak and Isaacs 1981). Our study found that while the experience of a fall in the past two years among those living alone significantly predicted use of personal call alarms at the bivariate level (but not for those living with others), it did not remain significant at the

\section{1}

Use of personal call alarms among community-dwelling older people

Nyman, S. R., \& Victor,

C.

R.

(2012).

Use

of

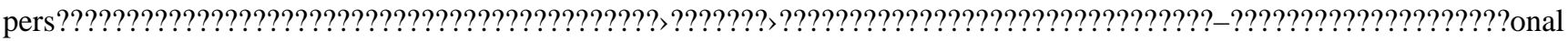
call alarms among community-

dwelling

older

people.

Ageing

\&

Society,

Published

online:

15

August,

DOI:

10.1017/S0144686X12000803.

(C)

Cambridge

University

Press

2012.

http://journals.cambridge.org/action/displayAbstract;jsessionid=CECAB498AA3794F4F65BFC3B843D6955.journals?fromPage= 
1

Use of personal call alarms among community-dwelling older people

Nyman, S. R., \& Victor,

C.

R.

(2012)

Use

of

pers?????????????????????????????????????????>?????????????????????????????????????-????????????????????onal call alarms among community-

dwelling

older

people.

Ageing

\&

Society,

Published

online:

15

August,

DOI:

10.1017/S0144686X12000803.

(C)

Cambridge

University

Press

2012.

http:/journals.cambridge.org/action/displayAbstract;jsessionid=CECAB498AA3794F4F65BFC3B843D6955.journals?fromPage=

multivariate level. In addition, our study found that use of personal call alarms was not significantly predicted by the number of falls experienced in the past two years for either those living alone or with others at both the bivariate and multivariate levels. Perhaps this reflects both the high frequency of falls among older people and that they are often interpreted as mild accidents rather than indicating a reduction in physical functioning (Kingston 2000; McKee 1998). Indeed, it may be that personal call alarms are only acquired after a fall has resulted in hip 
fracture or hospital admission, which occurs in approximately 5\% and $10 \%$ of falls among those aged 65+ and 75+ respectively (Rubenstein 2006). Perhaps the decision to acquire a personal call alarm rests on an older person's assessment of whether they are able to function independently (or with their existing level of support), and that the predictors of personal call alarm use that remained significant at the multivariate level in our study are more informative for this assessment than fall history.

1

Use of personal call alarms among community-dwelling older people

Nyman, S. R., \& Victor,

C.

$\mathrm{R}$

(2012).

Use

of

pers????????????????????????????????????????>???????>?????????????????????????????-???????????????????0nal call alarms among community-

dwelling

older

people.

Ageing

\&

Society,

Published

online:

15

August,

DOI:

10.1017/S0144686X12000803.

(C)

Cambridge

University

Press

2012.

http://journals.cambridge.org/action/displayAbstract;jsessionid=CECAB498AA3794F4F65BFC3B843D6955.journals?fromPage= 
1

Use of personal call alarms among community-dwelling older people

Nyman, S. R., \& Victor,

C.

R.

(2012)

Use

of

pers?????????????????????????????????????????>?????????????????????????????????????-????????????????????onal call alarms among community-

dwelling

older

people.

Ageing

\&

Society,

Published

online:

15

August,

DOI:

10.1017/S0144686X12000803.

(C)

Cambridge

University

Press

2012.

http:/journals.cambridge.org/action/displayAbstract;jsessionid=CECAB498AA3794F4F65BFC3B843D6955.journals?fromPage=

Of the myriad of possible factors that may predict use of personal call alarms (Charness and Boot 2009; Fisk et al. 2009; Rogers and Fisk 2010), our study indicated that older people in the community most likely to accept a personal call alarm are those living alone, who require assistance with everyday activities, who are relatively older, and those living with others who feel relatively less able to influence their environment. However, practitioners should be reminded that advances in technology raise both new possibilities and concerns (Sollie and Düwell 2009; 
Vedder and Custers 2009), and ethical concerns in particular (Bruce 2012; Ganyo, Dunn and Hope 2011; Punie 2005; Remmers 2010; Rosenberg et al. 2011). As our study underlines, assistive technology such as personal call alarms must be desirable as well as feasible (Karafyllis 2009). A novel approach that requires older people to self-report their daily activity and use of space shows promise as a way of collaboratively highlighting ways that homes can be made safer including the use of assistive technology (Bailey et al. 2011).

1

Use of personal call alarms among community-dwelling older people

Nyman, S. R., \& Victor,

C.

R.

(2012).

Use

of

pers???????????????????????????????????????>???????+???????????????????????????+???????????????????+0nal call alarms among community-

dwelling

older

people.

Ageing

\&

Society,

Published

online:

15

August,

DOI:

10.1017/S0144686X12000803.

(C)

Cambridge

University

Press

2012.

http://journals.cambridge.org/action/displayAbstract;jsessionid=CECAB498AA3794F4F65BFC3B843D6955.journals?fromPage= 
1

Use of personal call alarms among community-dwelling older people

Nyman, S. R., \& Victor,

C.

R.

(2012).

Use

of

pers?????????????????????????????????????????>?????????????????????????????????????-????????????????????onal call alarms among community-

dwelling

older

people.

Ageing

\&

Society,

Published

online:

15

August,

DOI:

10.1017/S0144686X12000803.

(C)

Cambridge

University

Press

2012.

http://journals.cambridge.org/action/displayAbstract;jsessionid=CECAB498AA3794F4F65BFC3B843D6955.journals?fromPage=

\section{Conclusion}

Despite the potential of personal call alarms to prevent serious injury, our findings suggest that they are very rarely used among community dwelling older people. It remains to be seen whether initiatives to increase use of personal call alarms can be effective or whether such alarms constitute too great a compromise to most older people's self-identity as usage may be perceived as a symbol of frailty and dependency. 


\section{References}

Audit Commission. 2004. Assistive Technology: Independence and Well-Being 4. Audit Commission, London.

Bailey, C., Foran, T.G., Ní Scanaill, C. and Dromey, B. 2011. Older adults, falls and technologies for independent living: A life space approach. Ageing \& Society, 31, 5, 829-48.

1

Use of personal call alarms among community-dwelling older people

Nyman, S. R., \& Victor,

C.

$\mathrm{R}$

(2012).

Use

of

pers?????????????????????????????????????????)??????>??????????????????????????????-????????????????????onal call alarms among community-

dwelling

older

people.

Ageing

\&

Society,

Published

online:

15

August,

DOI:

10.1017/S0144686X12000803.

(C)

Cambridge

University

Press

2012.

http://journals.cambridge.org/action/displayAbstract;jsessionid=CECAB498AA3794F4F65BFC3B843D6955.journals?fromPage= 
1

Use of personal call alarms among community-dwelling older people

Nyman, S. R., \& Victor,

C.

R.

(2012)

Use

of

pers?????????????????????????????????????????>??????+??????????????????????????????-????????????????????onal call alarms among community-

dwelling

older

people.

Ageing

\&

Society,

Published

online:

15

August,

DOI:

10.1017/S0144686X12000803.

(C)

Cambridge

University

Press

2012.

http:/journals.cambridge.org/action/displayAbstract;jsessionid=CECAB498AA3794F4F65BFC3B843D6955.journals?fromPage=

Barlow, J., Singh, D., Bayer, S. and Curry, R. 2007. A systematic review of the benefits of home telecare for frail elderly people and those with long-term conditions. Journal of Telemedicine and Telecare, 13, 4, 172-9.

Blane, D., Netuveli, G., and Montgomery, S.M. 2008. Quality of life, health and physiological status and change at older ages. Social Science \& Medicine, 66, 7, 1579-1587.

Blaschke, C.M., Freddolino, P.P. and Mullen, E.E. 2009. Ageing and technology: A review of the 
research literature. British Journal of Social Work, 39, 4, 641-56.

Braun, B.L. 1998. Knowledge and perception of fall-related risk factors and fall- reduction techniques among community-dwelling elderly individuals. Physical Therapy, 78, 12, 126276.

Brignell, M., Wootton, R. and Gray, L. 2007. The application of telemedicine to geriatric medicine. Age and Ageing, 36, 4, 369-74.

1

Use of personal call alarms among community-dwelling older people

Nyman, S. R., \& Victor,

C.

R.

(2012).

Use

of

pers????????????????????????????????????????>???????>?????????????????????????????-???????????????????0nal call alarms among community-

dwelling

older

people.

Ageing

\&

Society,

Published

online:

15

August,

DOI:

10.1017/S0144686X12000803.

(C)

Cambridge

University

Press

2012.

http://journals.cambridge.org/action/displayAbstract;jsessionid=CECAB498AA3794F4F65BFC3B843D6955.journals?fromPage= 
1

Use of personal call alarms among community-dwelling older people

Nyman, S. R., \& Victor,

C.

R.

(2012).

Use

of

pers?????????????????????????????????????????>?????????????????????????????????????-????????????????????onal call alarms among community-

dwelling

older

people.

Ageing

\&

Society,

Published

online:

15

August,

DOI:

10.1017/S0144686X12000803.

(C)

Cambridge

University

Press

2012.

http:/journals.cambridge.org/action/displayAbstract;jsessionid=CECAB498AA3794F4F65BFC3B843D6955.journals?fromPage=

Brownsell, S., Aldred, H. and Hawley, M.S. 2007. The role of telecare in supporting the needs of elderly people. Journal of Telemedicine and Telecare, 13, 6, 293-7.

Brownsell, S., Bradley, D.A., Bragg, R., Catlin, P. and Carlier, J. 2000. Do community alarm users want telecare? Journal of Telemedicine and Telecare, 6, 4, 199-204.

Brownsell, S. and Hawley, M.S. 2004. Fall detectors: Do they work or reduce the fear of falling? Housing, Care and Support, 7, 1, 18-24. 
Brownsell, S. and Hawley, M.S. 2006. Telecare and its role in falls management. In Wootton, R., Dimmick S. and Kvedar J.(eds), Home Telehealth: Connecting Care Within the Community. Royal Society of Medicine, London, 108-20.

Bruce, C.R. 2012. Informed decision making for in-home use of motion sensor-based monitoring technologies. Gerontologist, 52, 3, 317-324.

Cameron, I.D., Murray, G.R., Gillespie, L.D., Robertson, M.C., Hill, K.D., Cumming, R.G. and

1

Use of personal call alarms among community-dwelling older people

Nyman, S. R., \& Victor,

C.

R.

(2012).

Use

of

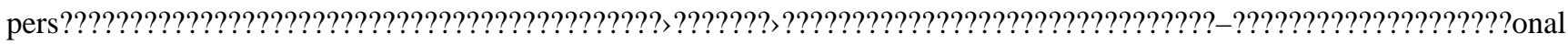
call alarms among community-

dwelling

older

people.

Ageing

\&

Society,

Published

online:

15

August,

DOI:

10.1017/S0144686X12000803.

(C)

Cambridge

University

Press

2012.

http://journals.cambridge.org/action/displayAbstract;jsessionid=CECAB498AA3794F4F65BFC3B843D6955.journals?fromPage= 
1

Use of personal call alarms among community-dwelling older people

Nyman, S. R., \& Victor,

C.

R.

(2012)

Use

of

pers?????????????????????????????????????????>??????+??????????????????????????????-????????????????????onal call alarms among community-

dwelling

older

people.

Ageing

\&

Society,

Published

online:

15

August,

DOI:

10.1017/S0144686X12000803.

(C)

Cambridge

University

Press

2012.

http:/journals.cambridge.org/action/displayAbstract;jsessionid=CECAB498AA3794F4F65BFC3B843D6955.journals?fromPage=

Kerse, N. 2010. Interventions for preventing falls in older people in nursing care facilities and hospitals. Cochrane Database of Systematic Reviews, 1, Art. No.: CD005465, DOI: 10.1002/14651858.CD005465.pub2.

Cameron, I.D. and Quine, S. 1994. External hip protectors: Likely noncompliance among highrisk elderly people living in the community. Archives of Gerontology and Geriatrics, 19, 3, 273-81. 
Charness, N. and Boot, W.R. 2009. Aging and information technology use. Current Directions in Psychological Science, 18, 5, 253-258.

Charness, N. and Czaja, S.J. 2005. Adaptation to new technologies. In Johnson, M.L., Bengtson, V.L., Coleman, P.G. and Kirkwood, T.B.L.(eds), The Cambridge Handbook of Age and Ageing. Cambridge University Press, Cambridge, 662-9.

De San Miguel, K. and Lewin, G. 2008. Personal emergency alarms: What impact do they have

1

Use of personal call alarms among community-dwelling older people

Nyman, S. R., \& Victor,

C.

$\mathrm{R}$.

(2012).

Use

of

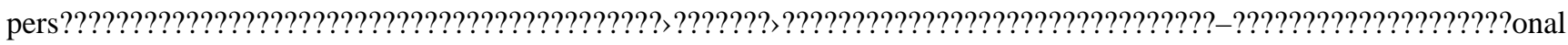
call alarms among community-

dwelling

older

people.

Ageing

$\&$

Society,

Published

online:

15

August,

DOI:

10.1017/S0144686X12000803.

(C)

Cambridge

University

Press

2012.

http://journals.cambridge.org/action/displayAbstract;jsessionid=CECAB498AA3794F4F65BFC3B843D6955.journals?fromPage= 
1

Use of personal call alarms among community-dwelling older people

Nyman, S. R., \& Victor,

C.

R.

(2012).

Use

of

pers?????????????????????????????????????????>?????????????????????????????????????-????????????????????onal call alarms among community-

dwelling

older

people.

Ageing

\&

Society,

Published

online:

15

August,

DOI:

10.1017/S0144686X12000803.

(C)

Cambridge

University

Press

2012.

http:/journals.cambridge.org/action/displayAbstract;jsessionid=CECAB498AA3794F4F65BFC3B843D6955.journals?fromPage=

on older people's lives? Australasian Journal on Ageing, 27, 2, 103-5.

Department of Health. 2009. Telecare. Department of Health, London.

Dibner, A.S., Lowy, L. and Morris, J.N. 1982. Usage and acceptance of an emergency alarm system by the frail elderly. The Gerontologist, 22, 6, 538-9.

Field, A. 2009. Discovering statistics using SPSS, 3rd edn. Sage, London.

Fisk, A.D., Rogers, W.A., Charness, N., Czaja, S.J. and Sharit, J. 2009. Designing for older 
adults: Principles and creative human factors approaches, 2nd edn. CRC Press, Taylor \& Francis Group, London.

Fleming, J., Brayne, C. and the Cambridge City over-75s Cohort (CC75C) study collaboration 2008. Inability to get up after falling, subsequent time on floor, and summoning help: Prospective cohort study in people over 90. BMJ, Published Online: 17 November, 337, DOI: 10.1136/bmj.a2227.

1

Use of personal call alarms among community-dwelling older people

Nyman, S. R., \& Victor,

C.

R.

(2012).

Use

of

pers????????????????????????????????????????>???????>?????????????????????????????-???????????????????onal call alarms among community-

dwelling

older

people.

Ageing

$\&$

Society,

Published

online:

15

August,

DOI:

10.1017/S0144686X12000803.

(C)

Cambridge

University

Press

2012.

http://journals.cambridge.org/action/displayAbstract;jsessionid=CECAB498AA3794F4F65BFC3B843D6955.journals?fromPage= 
1

Use of personal call alarms among community-dwelling older people

Nyman, S. R., \& Victor,

C.

R.

(2012)

Use

of

pers?????????????????????????????????????????>?????????????????????????????????????-????????????????????onal call alarms among community-

dwelling

older

people.

Ageing

\&

Society,

Published

online:

15

August,

DOI:

10.1017/S0144686X12000803.

(C)

Cambridge

University

Press

2012.

http:/journals.cambridge.org/action/displayAbstract;jsessionid=CECAB498AA3794F4F65BFC3B843D6955.journals?fromPage=

Fleming, J., Matthews, F.E., Brayne, C. and the Cambridge City over-75s Cohort (CC75C) study collaboration 2008. Falls in advanced old age: Recalled falls and prospective follow-up of over-90-year-olds in the Cambridge City over-75s Cohort study. BMC Geriatrics, 8, e6.

Ganyo, M., Dunn, M. and Hope, T. 2011. Ethical issues in the use of fall detectors. Ageing \& Society, 31, 8, 1350-1367.

Gilleard, C., Hyde, M. and Higgs, P. 2007. Community and communication in the third age: The 
impact of internet and cell phone use on attachment to place in later life in England. Journal of Gerontology: Social Sciences, 62B, 4, S276-S283.

Gillespie, L.D., Robertson, M.C., Gillespie, W.J., Lamb, S.E., Gates, S., Cumming, R.G. and

Rowe, B.H. 2009. Interventions for preventing falls in older people living in the community. Cochrane Database of Systematic Reviews, 2, Art. No.: CD007146, DOI: 10.1002/14651858.CD007146.pub2.

1

Use of personal call alarms among community-dwelling older people

Nyman, S. R., \& Victor,

C.

R.

(2012).

Use

of

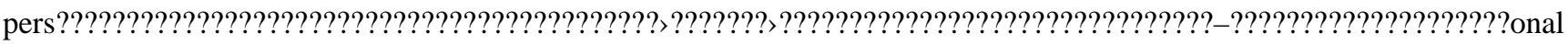
call alarms among community-

dwelling

older

people.

Ageing

$\&$

Society,

Published

online:

15

August,

DOI:

10.1017/S0144686X12000803.

(C)

Cambridge

University

Press

2012.

http://journals.cambridge.org/action/displayAbstract;jsessionid=CECAB498AA3794F4F65BFC3B843D6955.journals?fromPage= 
1

Use of personal call alarms among community-dwelling older people

Nyman, S. R., \& Victor,

C.

R.

(2012).

Use

of

pers?????????????????????????????????????????>??????+??????????????????????????????-????????????????????onal call alarms among community-

dwelling

older

people.

Ageing

\&

Society,

Published

online:

15

August,

DOI:

10.1017/S0144686X12000803.

(C)

Cambridge

University

Press

2012.

http:/journals.cambridge.org/action/displayAbstract;jsessionid=CECAB498AA3794F4F65BFC3B843D6955.journals?fromPage=

Gitlin, L.N., Luborsky, M.R. and Schemm, R.L. 1998. Emerging concerns of older stroke patients about assistive device use. The Gerontologist, 38, 2, 169-180.

Gurley, R.J., Lum, N., Sande, M., Lo, B. and Katz, M.H. 1996. Persons found in their homes helpless or dead. New England Journal of Medicine, 334, 26, 1710-6.

Hartholt, K.A., van Beeck, E.F., Polinder, S., van der Velde, N., van Lieshout, E.M., Panneman, M.J., van der Cammen, T.J., and Patka, P. 2011. Societal consequences of falls in the older 
population: Injuries, healthcare costs, and long-term reduced quality of life. Journal of Trauma, 71, 3, 748-753.

Horton, K. 2008. Falls in older people: The place of telemonitoring in rehabilitation. Journal of Rehabilitation Research \& Development, 45, 8, 1183-1194.

Hyde, M., Wiggins, R.D., Higgs, P. and Blane, D.B. 2003. A measure of quality of life in early old age: The theory, development and properties of a needs satisfaction model (CASP-19).

1

Use of personal call alarms among community-dwelling older people

Nyman, S. R., \& Victor,

C.

R.

(2012).

Use

of

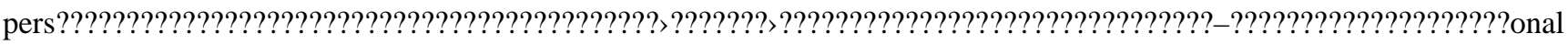
call alarms among community-

dwelling

older

people.

Ageing

\&

Society,

Published

online:

15

August,

DOI:

10.1017/S0144686X12000803.

(C)

Cambridge

University

Press

2012.

http://journals.cambridge.org/action/displayAbstract;jsessionid=CECAB498AA3794F4F65BFC3B843D6955.journals?fromPage= 
1

Use of personal call alarms among community-dwelling older people

Nyman, S. R., \& Victor,

C.

R.

(2012).

Use

of

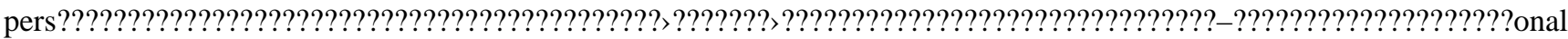

call alarms among community-

dwelling

older

people.

Ageing

\&

Society,

Published

online:

15

August,

DOI:

10.1017/S0144686X12000803.

(c)

Cambridge

University

Press

2012.

http://journals.cambridge.org/action/displayAbstract;jsessionid=CECAB498AA3794F4F65BFC3B843D6955.journals?fromPage=

Aging \& Mental Health, 7, 3, 186-94.

Johnston, K., Grimmer-Somers, K., and Sutherland, M. 2010. Perspectives on use of personal alarms by older fallers. International Journal of General Medicine, 3, 231-237.

Kannus, P., Sievanen, H., Palvanen, M., Jarvinen, T. and Parkkari, J. 2005. Prevention of falls and consequent injuries in elderly people. Lancet, 366, 9500, 1885-93.

Karafyllis, N.C. 2009. Facts or fiction? A critique on vision assessment as a tool for technology 
assessment. In Sollie, P. and Düwell, M.(eds), Evaluating New Technologies:

Methodological Problems for the Ethical Assessment of Technology Developments.

Springer, Milton Keynes, UK, 93-117.

Kiel, D.P., Magaziner, J., Zimmerman, S., Ball, L., Barton, B.A., Brown, K.M., Stone, J.P., Dewkett, D. and Birge, S.J. 2007. Efficacy of a hip protector to prevent hip fracture in nursing home residents: The HIP PRO randomized controlled trial. Journal of the American

1

Use of personal call alarms among community-dwelling older people

Nyman, S. R., \& Victor,

C.

R.

(2012).

Use

of

pers????????????????????????????????????????>???????>?????????????????????????????-???????????????????onal call alarms among community-

dwelling

older

people.

Ageing

\&

Society,

Published

online:

15

August,

DOI:

10.1017/S0144686X12000803.

(C)

Cambridge

University

Press

2012.

http://journals.cambridge.org/action/displayAbstract;jsessionid=CECAB498AA3794F4F65BFC3B843D6955.journals?fromPage= 
1

Use of personal call alarms among community-dwelling older people

Nyman, S. R., \& Victor,

C.

R.

(2012)

Use

of

pers?????????????????????????????????????????>??????+??????????????????????????????-????????????????????onal call alarms among community-

dwelling

older

people.

Ageing

\&

Society,

Published

online:

15

August,

DOI:

10.1017/S0144686X12000803.

(C)

Cambridge

University

Press

2012.

http:/journals.cambridge.org/action/displayAbstract;jsessionid=CECAB498AA3794F4F65BFC3B843D6955.journals?fromPage=

Medical Association, 298, 4, 413-22.

Kingston, P. 2000. Falls in later life: Status passage and preferred identities as a new orientation. Health, 4, 2, 216-233.

Lai, C.K.Y., Chung, J.C.C., Leung, N.K.L., Wong, J.C.T. and Mak, D.P.S. 2010. A survey of older Hong Kong people's perceptions of telecommunication technologies and telecare devices. Journal of Telemedicine and Telecare, 16, 8, 441-6. 
Lang, I.A., Llewellyn, D.J., Alexander, K. and Melzer, D. 2008. Obesity, physical function, and mortality in older adults. Journal of the American Geriatrics Society, 56, 8, 1474-1478.

Larsson, K. and Thorslund, M. 2002. Does gender matter? Differences in patterns of informal support and formal services in a Swedish urban elderly population. Research on Aging, 24, 3, 308-336.

Lee, J.S., Hurley, M.J., Carew, D., Fisher, R., Kiss, A. and Drummond, N. 2007. A randomized

1

Use of personal call alarms among community-dwelling older people

Nyman, S. R., \& Victor,

C.

$\mathrm{R}$.

(2012).

Use

of

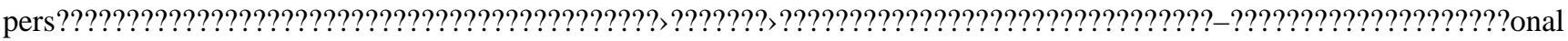
call alarms among community-

dwelling

older

people.

Ageing

\&

Society,

Published

online:

15

August,

DOI:

10.1017/S0144686X12000803.

(C)

Cambridge

University

Press

2012.

http://journals.cambridge.org/action/displayAbstract;jsessionid=CECAB498AA3794F4F65BFC3B843D6955.journals?fromPage= 
1

Use of personal call alarms among community-dwelling older people

Nyman, S. R., \& Victor,

C.

R.

(2012)

Use

of

pers?????????????????????????????????????????>??????+??????????????????????????????-????????????????????onal call alarms among community-

dwelling

older

people.

Ageing

\&

Society,

Published

online:

15

August,

DOI:

10.1017/S0144686X12000803.

(C)

Cambridge

University

Press

2012.

http:/journals.cambridge.org/action/displayAbstract;jsessionid=CECAB498AA3794F4F65BFC3B843D6955.journals?fromPage=

clinical trial to assess the impact on an emergency response system on anxiety and health care use among older emergency patients after a fall. Academic Emergency Medicine, 14, 4, $301-8$.

Lee, R.Y.W. and Carlisle, A.J. 2011. Detection of falls using accelerometers and mobile phone technology. Age and Ageing, 40, 6, 690-696.

Leone, A., Diraco, G. and Siciliano, P. 2011. Detecting falls with 3D range camera in ambient 
assisted living applications: A preliminary study. Medical Engineering \& Physics, 33, 6, 770-81.

Levine, D.A. and Tideiksaar, R. 1995. Personal emergency response systems: Factors associated with use among older persons. Mount Sinai Journal of Medicine, 62, 4, 293-7.

Logan, P.A., Murphy, A., Drummond, A.E.R., Bailey, S., Radford, K.A., Gladman, J.R.F., Walker, M.F., Robertson, K., Edmans, J.A. and Conroy, S. 2007. An investigation of the

1

Use of personal call alarms among community-dwelling older people

Nyman, S. R., \& Victor,

C.

R.

(2012).

Use

of

pers????????????????????????????????????????>???????>?????????????????????????????-???????????????????onal call alarms among community-

dwelling

older

people.

Ageing

\&

Society,

Published

online:

15

August,

DOI:

10.1017/S0144686X12000803.

(C)

Cambridge

University

Press

2012.

http://journals.cambridge.org/action/displayAbstract;jsessionid=CECAB498AA3794F4F65BFC3B843D6955.journals?fromPage= 
1

Use of personal call alarms among community-dwelling older people

Nyman, S. R., \& Victor,

C.

R.

(2012).

Use

of

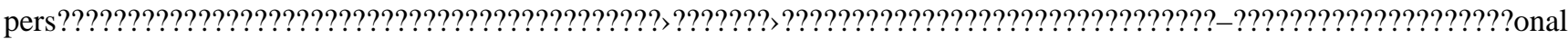

call alarms among community-

dwelling

older

people.

Ageing

\&

Society,

Published

online:

15

August,

DOI:

10.1017/S0144686X12000803.

(c)

Cambridge

University

Press

2012.

http://journals.cambridge.org/action/displayAbstract;jsessionid=CECAB498AA3794F4F65BFC3B843D6955.journals?fromPage=

number and cost of assistive devices used by older people who had fallen and called a 999 ambulance. British Journal of Occupational Therapy, 70, 11, 475-8.

Londei, S.T., Rousseau, J., Ducharme, F., St-Arnaud, A., Meunier, J., Saint-Arnaud, J. and

Giroux, F. 2009. An intelligent videomonitoring system for fall detection at home:

Perceptions of elderly people. Journal of Telemedicine and Telecare, 15, 8, 383-90.

Lord, S.R., Sherrington, C., Menz, H.B. \& Close, J.C.T. 2007. Falls in Older People: Risk 
Factors and Strategies for Prevention, 2nd edn. Cambridge University Press, Cambridge. Mann, W.C., Belchior, P., Tomita, M.R. and Kemp, B.J. 2005. Use of personal emergency response systems by older individuals with disabilities. Assistive Technology, 17, 1, 82-8.

Marmot, M. and Breeze, E. 2008. Introduction. In Banks, J., Breeze, E., Lessof, C. and Nazroo, J.(eds), Living in the 21st Century: Older People in England: The 2006 English Longitudinal Study of Ageing (Wave 3). The Institute for Fiscal Studies, London, 1-18.

1

Use of personal call alarms among community-dwelling older people

Nyman, S. R., \& Victor,

C.

$\mathrm{R}$.

(2012).

Use

of

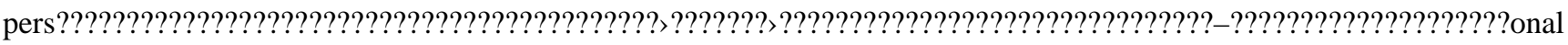
call alarms among community-

dwelling

older

people.

Ageing

\&

Society,

Published

online:

15

August,

DOI:

10.1017/S0144686X12000803.

(C)

Cambridge

University

Press

2012.

http://journals.cambridge.org/action/displayAbstract;jsessionid=CECAB498AA3794F4F65BFC3B843D6955.journals?fromPage= 
1

Use of personal call alarms among community-dwelling older people

Nyman, S. R., \& Victor,

C.

R.

(2012).

Use

of

pers?????????????????????????????????????????>?????????????????????????????????????-????????????????????onal call alarms among community-

dwelling

older

people.

Ageing

\&

Society,

Published

online:

15

August,

DOI:

10.1017/S0144686X12000803.

(C)

Cambridge

University

Press

2012.

http:/journals.cambridge.org/action/displayAbstract;jsessionid=CECAB498AA3794F4F65BFC3B843D6955.journals?fromPage=

Marmot, M., Nazroo, J., Banks, J., Blundell, R., Erens, B., Lessof, C. and Huppert, F. A. 2008. English Longitudinal Study of Ageing: Wave 0 (1998, 1999 and 2001) and Waves 1-3 (20022007), 10th edn: SN. 5050 [computer file]. UK Data Archive [distributor], Colchester, UK.

Martin, S., Kelly, G., Kernohan, W.G., McCreight, B. and Nugent, C. 2008. Smart home technologies for health and social care support. Cochrane Database of Systematic Reviews, 4, Art. No.: CD006412, DOI: 10.1002/14651858.CD006412.pub2. 
Matlabi, H., Parker, S.G. and McKee, K. 2011. The contribution of home-based technology to older people's quality of life in extra care housing. BMC Geriatrics, 11, e68.

McCreadie, C. and Tinker, A. 2005. The acceptability of assistive technology to older people. Ageing \& Society, 25, 1, 91-110.

McKee, K.J. 1998. The body drop: A framework for understanding recovery from falls in older people. Generations Review, 8, 4, 11-12.

1

Use of personal call alarms among community-dwelling older people

Nyman, S. R., \& Victor,

C.

$\mathrm{R}$.

(2012).

Use

of

pers????????????????????????????????????????>???????>?????????????????????????????-???????????????????onal call alarms among community-

dwelling

older

people.

Ageing

$\&$

Society,

Published

online:

15

August,

DOI:

10.1017/S0144686X12000803.

(C)

Cambridge

University

Press

2012.

http://journals.cambridge.org/action/displayAbstract;jsessionid=CECAB498AA3794F4F65BFC3B843D6955.journals?fromPage= 
1

Use of personal call alarms among community-dwelling older people

Nyman, S. R., \& Victor,

C.

R.

(2012)

Use

of

pers?????????????????????????????????????????>?????????????????????????????????????-????????????????????onal call alarms among community-

dwelling

older

people.

Ageing

\&

Society,

Published

online:

15

August,

DOI:

10.1017/S0144686X12000803.

(C)

Cambridge

University

Press

2012.

http:/journals.cambridge.org/action/displayAbstract;jsessionid=CECAB498AA3794F4F65BFC3B843D6955.journals?fromPage=

McMunn, A., Nazroo, J., Wahrendorf, M., Breeze, E. and Zaninotto, P. 2009. Participation in socially-productive activities, reciprocity and wellbeing in later life: Baseline results in England. Ageing \& Society, 29, 5, 765-82.

Mihailidis, A., Cockburn, A., Longley, C. and Boger, J. 2008. The acceptability of home monitoring technology among community-dwelling older adults and baby boomers. Assistive Technology, 20, 1, 1-12. 
National Statistics. 2010a. Mid Year Population Estimates 2006 [Excel data file]. Available online at: http://www.statistics.gov.uk/statbase/Product.asp?vlnk=15106 [Accessed August 2, 2010].

National Statistics. 2010b. Mid Year Population Estimates 2007 [Excel data file] Available online at: http://www.statistics.gov.uk/statbase/Product.asp?vlnk=15106 [Accessed August 2, 2010].

\section{1}

Use of personal call alarms among community-dwelling older people

Nyman, S. R., \& Victor,

C.

R.

(2012).

Use

of

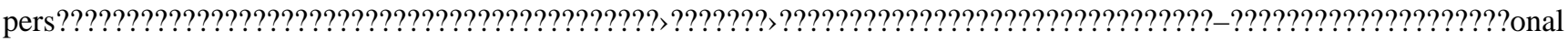
call alarms among community-

dwelling

older

people.

Ageing

\&

Society,

Published

online:

15

August,

DOI:

10.1017/S0144686X12000803.

(C)

Cambridge

University

Press

2012.

http://journals.cambridge.org/action/displayAbstract;jsessionid=CECAB498AA3794F4F65BFC3B843D6955.journals?fromPage= 
1

Use of personal call alarms among community-dwelling older people

Nyman, S. R., \& Victor,

C.

R.

(2012).

Use

of

pers?????????????????????????????????????????>??????+??????????????????????????????-????????????????????onal call alarms among community-

dwelling

older

people.

Ageing

\&

Society,

Published

online:

15

August,

DOI:

10.1017/S0144686X12000803.

(C)

Cambridge

University

Press

2012.

http:/journals.cambridge.org/action/displayAbstract;jsessionid=CECAB498AA3794F4F65BFC3B843D6955.journals?fromPage=

Noury, N., Rumeau, P., Bourke, A.K., ÓLaighin, G. and Lundy, J.E. 2008. A proposal for the classification and evaluation of fall detectors. IRBM, 29, 6, 340-9.

Nunn, S., Cox, K., Wood, N. \& Scholes, S. 2009. English Longitudinal Study of Ageing (ELSA), Wave 3 Core Dataset, Phase 2 Deposit: User Guide Version 1. National Centre for Social Research, London.

Nyman, S.R. and Oliver, D. 2010. Preventing falls and avoiding restraint. In Hughes, R.(ed), 
Rights, Risks and Restraint-Free Care of Older People. Jessica Kingsley Publishers, London, 167-77.

Oliver, D. 2004. Prevention of falls in hospital inpatients: Agendas for research and practice. Age and Ageing, 33, 4, 328-30.

Ozcan, A., Donat, H., Gelecek, N., Ozdirenc, M., and Karadibak, D. 2005. The relationship between risk factors for falling and the quality of life in older adults. BMC Public Health,

1

Use of personal call alarms among community-dwelling older people

Nyman, S. R., \& Victor,

C.

R.

(2012).

Use

of

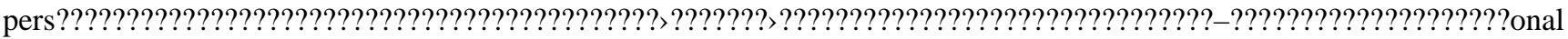
call alarms among community-

dwelling

older

people.

Ageing

\&

Society,

Published

online:

15

August,

DOI:

10.1017/S0144686X12000803.

(C)

Cambridge

University

Press

2012.

http://journals.cambridge.org/action/displayAbstract;jsessionid=CECAB498AA3794F4F65BFC3B843D6955.journals?fromPage= 
1

Use of personal call alarms among community-dwelling older people

Nyman, S. R., \& Victor,

C.

R.

(2012)

Use

of

pers?????????????????????????????????????????>?????????????????????????????????????-????????????????????onal call alarms among community-

dwelling

older

people.

Ageing

\&

Society,

Published

online:

15

August,

DOI:

10.1017/S0144686X12000803.

(C)

Cambridge

University

Press

2012.

http:/journals.cambridge.org/action/displayAbstract;jsessionid=CECAB498AA3794F4F65BFC3B843D6955.journals?fromPage=

5, e90.

Pain, H., Gale, C.R., Watson, C., Cox, V., Cooper, C. and Sayer, A.A. 2007. Readiness of elders to use assistive devices to maintain their independence in the home. Age and Ageing, 36, 4, 465-7.

Parker, M.J., Gillespie, W.J. and Gillespie, L.D. 2005. Hip protectors for preventing hip fractures in older people. Cochrane Database of Systematic Reviews, 3, Art. No.: CD001255, DOI: 
10.1002/14651858.CD001255.pub3.

Parker, M.J., Gillespie, W.J. and Gillespie, L.D. 2006. Effectiveness of hip protectors for preventing hip fractures in elderly people: Systematic review. BMJ, 332, 7541, 571-4.

Porter, E.J. and Ganong, L.H. 2002. Considering the use of a personal emergency response system: An experience of frail, older women. Care Management Journals: Journal of Case Management: Journal of Long Term Home Health Care, 3, 4, 192-8.

1

Use of personal call alarms among community-dwelling older people

Nyman, S. R., \& Victor,

C.

R.

(2012).

Use

of

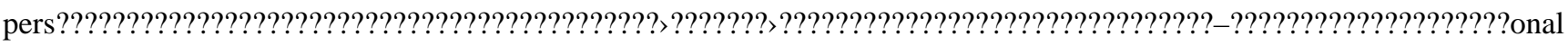
call alarms among community-

dwelling

older

people.

Ageing

$\&$

Society,

Published

online:

15

August,

DOI:

10.1017/S0144686X12000803.

(C)

Cambridge

University

Press

2012.

http://journals.cambridge.org/action/displayAbstract;jsessionid=CECAB498AA3794F4F65BFC3B843D6955.journals?fromPage= 
1

Use of personal call alarms among community-dwelling older people

Nyman, S. R., \& Victor,

C.

R.

(2012)

Use

of

pers?????????????????????????????????????????>??????+??????????????????????????????-????????????????????onal call alarms among community-

dwelling

older

people.

Ageing

\&

Society,

Published

online:

15

August,

DOI:

10.1017/S0144686X12000803.

(C)

Cambridge

University

Press

2012.

http:/journals.cambridge.org/action/displayAbstract;jsessionid=CECAB498AA3794F4F65BFC3B843D6955.journals?fromPage=

Prado-Velasco, M., del Rio-Cidoncha, M.G. and Ortiz-Martin, R. 2006. The inescapable smart impact detection system (ISIS): An ubiquitous and personalized fall detector based on a distributed "divide and conquer strategy". Proceedings of the 30th IEEE EMBS Annual International Conference, Vancouver, British Columbia, Canada, August 20-24, 3332-5.

Pressler, K.A. and Ferraro, K.F. 2010. Assistive device use as a dynamic acquisition process in later life. Gerontologist, 50, 3, 371-81. 
Punie, Y. 2005. The future of ambient intelligence in Europe - the need for more everyday life. In Silverstone, R.(ed), Media Technology and Everyday Life in Europe: From Information to Communication. Ashgate, Aldershot, UK, 159-77.

Radloff, L.S. 1977. The CES-D scale: A self-report depression scale for research in general population. Applied Psychological Measurement, 1, 3, 385-401.

Rajendran, P., Corcoran, A., Kinosian, B. and Alwan, M. 2008. Falls, fall prevention, and fall

1

Use of personal call alarms among community-dwelling older people

Nyman, S. R., \& Victor,

C.

R.

(2012).

Use

of

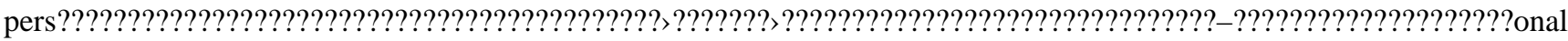
call alarms among community-

dwelling

older

people.

Ageing

\&

Society,

Published

online:

15

August,

DOI:

$10.1017 / \mathrm{S} 0144686 \mathrm{X} 12000803$.

(C)

Cambridge

University

Press

2012.

http://journals.cambridge.org/action/displayAbstract;jsessionid=CECAB498AA3794F4F65BFC3B843D6955.journals?fromPage= 
1

Use of personal call alarms among community-dwelling older people

Nyman, S. R., \& Victor,

C.

R.

(2012)

Use

of

pers?????????????????????????????????????????>?????????????????????????????????????-????????????????????onal call alarms among community-

dwelling

older

people.

Ageing

\&

Society,

Published

online:

15

August,

DOI:

10.1017/S0144686X12000803.

(C)

Cambridge

University

Press

2012.

http:/journals.cambridge.org/action/displayAbstract;jsessionid=CECAB498AA3794F4F65BFC3B843D6955.journals?fromPage=

detection technologies. In Alwan, M. and Felder R.(eds), Aging Medicine, Eldercare

Technology for Clinical Practitioners. Humana Press, New Jersey, 187-202.

Remmers, H. 2010. Environments for ageing, assistive technology and self-determination: Ethical perspectives. Informatics for Health \& Social Care, 35, 3-4, 200-10.

Roelands, M., Van Oost, P., Buysse, A. and Depoorter, A. 2002. Awareness among communitydwelling elderly of assistive devices for mobility and self-care and attitudes towards their 
use. Social Science \& Medicine, 54, 9, 1441-1451.

Roelands, M., Van Oost, P., Depoorter, A. and Buysse, A. 2002. A social-cognitive model to predict the use of assistive devices for mobility and self-care in elderly people. The Gerontologist, 42, 1, 39-50.

Rogers, W.A. and Fisk, A.D. 2010. Toward a psychological science of advanced technology design for older adults. Journal of Gerontology: Psychological Sciences, 65B, 6, 645-653.

1

Use of personal call alarms among community-dwelling older people

Nyman, S. R., \& Victor,

C.

R.

(2012).

Use

of

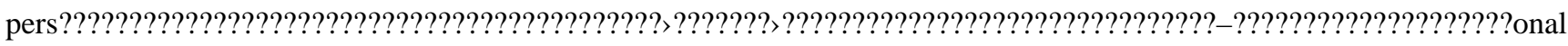
call alarms among community-

dwelling

older

people.

Ageing

\&

Society,

Published

online:

15

August,

DOI:

10.1017/S0144686X12000803.

(C)

Cambridge

University

Press

2012.

http://journals.cambridge.org/action/displayAbstract;jsessionid=CECAB498AA3794F4F65BFC3B843D6955.journals?fromPage= 
1

Use of personal call alarms among community-dwelling older people

Nyman, S. R., \& Victor,

C.

R.

(2012)

Use

of

pers?????????????????????????????????????????>??????+??????????????????????????????-????????????????????onal call alarms among community-

dwelling

older

people.

Ageing

\&

Society,

Published

online:

15

August,

DOI:

10.1017/S0144686X12000803.

(C)

Cambridge

University

Press

2012.

http:/journals.cambridge.org/action/displayAbstract;jsessionid=CECAB498AA3794F4F65BFC3B843D6955.journals?fromPage=

Rosenberg, L., Kottorp, A. and Nygård, L. 2011. Readiness for technology use with people with dementia: The perspectives of significant others. Journal of Applied Gerontology, Published Online First: 28 January, DOI: 10.1177/0733464810396873.

Rubenstein, L.Z. 2006. Falls in older people: Epidemiology, risk factors, and strategies for prevention. Age and Ageing, 35, S2, ii37-ii41.

Scholes, S., Cox, K. and Lessof, C. 2008. Methodology. In Banks, J., Breeze E., Lessof C. and 
Nazroo J.(eds), Living in the 21st Century: Older People in England: The 2006 English Longitudinal Study Of Ageing (Wave 3). The Institute for Fiscal Studies, London, 281-303. Selwyn, N. 2004. The information aged: A qualitative study of older adults' use of information and communications technology. Journal of Aging Studies, 18, 4, 369-384.

Selwyn, N., Gorard, S., Furlong, J. and Madden, L. 2003. Older adults' use of information and communications technology in everyday life. Ageing \& Society, 23, 5, 561-82.

1

Use of personal call alarms among community-dwelling older people

Nyman, S. R., \& Victor,

C.

$\mathrm{R}$.

(2012).

Use

of

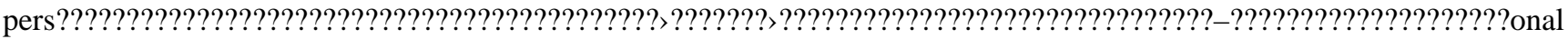
call alarms among community-

dwelling

older

people.

Ageing

\&

Society,

Published

online:

15

August,

DOI:

10.1017/S0144686X12000803.

(C)

Cambridge

University

Press

2012.

http://journals.cambridge.org/action/displayAbstract;jsessionid=CECAB498AA3794F4F65BFC3B843D6955.journals?fromPage= 
1

Use of personal call alarms among community-dwelling older people

Nyman, S. R., \& Victor,

C.

R.

(2012).

Use

of

pers?????????????????????????????????????????>??????+??????????????????????????????-????????????????????onal call alarms among community-

dwelling

older

people.

Ageing

\&

Society,

Published

online:

15

August,

DOI:

10.1017/S0144686X12000803.

(C)

Cambridge

University

Press

2012.

http:/journals.cambridge.org/action/displayAbstract;jsessionid=CECAB498AA3794F4F65BFC3B843D6955.journals?fromPage=

Skelton, D.A. \& Todd, C.J. 2004. What Are the Main Risk Factors for Falls Amongst Older People and What Are the Most Effective Interventions to Prevent These Falls? Health Evidence Network, World Health Organization, Copenhagen.

Sollie, P. and Düwell, M. 2009. Evaluating new technologies: An introduction. In Sollie, P. and Düwell, M.(eds), Evaluating New Technologies: Methodological Problems for the Ethical Assessment of Technology Developments. Springer, Milton Keynes, UK, 1-8. 
Stafford, M., McMunn, A. and de Vogli, R. 2011. Neighbourhood social environment and depressive symptoms in mid-life and beyond. Ageing \& Society, 31, 6, 893-910.

Stafford, M., McMunn, A., Zaninotto, P. and Nazroo, J. 2011. Positive and negative exchanges in social relationships as predictors of depression: Evidence from the English Longitudinal Study of Aging. Journal of Aging and Health, 23, 4, 607-628.

Steel, D.M. and Gray, M.A. 2009. Baby boomers' use and perception of recommended assistive

1

Use of personal call alarms among community-dwelling older people

Nyman, S. R., \& Victor,

C.

R.

(2012).

Use

of

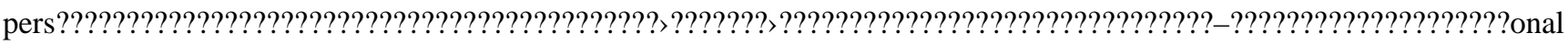
call alarms among community-

dwelling

older

people.

Ageing

\&

Society,

Published

online:

15

August,

DOI:

10.1017/S0144686X12000803.

(C)

Cambridge

University

Press

2012.

http://journals.cambridge.org/action/displayAbstract;jsessionid=CECAB498AA3794F4F65BFC3B843D6955.journals?fromPage= 
1

Use of personal call alarms among community-dwelling older people

Nyman, S. R., \& Victor,

C.

R.

(2012)

Use

of

pers?????????????????????????????????????????>??????+??????????????????????????????-????????????????????onal call alarms among community-

dwelling

older

people.

Ageing

\&

Society,

Published

online:

15

August,

DOI:

10.1017/S0144686X12000803.

(C)

Cambridge

University

Press

2012.

http:/journals.cambridge.org/action/displayAbstract;jsessionid=CECAB498AA3794F4F65BFC3B843D6955.journals?fromPage=

technology: A systematic review. Disability and Rehabilitation: Assistive Technology, 4, 3, 129-136.

Stevens, K.N., Lang, I.A., Guralnik, J.M. and Melzer, D. 2008. Epidemiology of balance and dizziness in a national population: Findings from the English Longitudinal Study of Ageing. Age and Ageing, 37, 3, 300-305.

Tabassum, F., Verropoulou, G., Tsimbos, C., Gjonca, E. and Breeze, E. 2009. Socio-economic 
inequalities in physical functioning: A comparative study of English and Greek elderly men. Ageing \& Society, 29, 7, 1123-40.

Takahashi, P.Y., Pecina, J.L., Upatising, B., Chaudhry, R., Shah, N.D., Van Houten, H., Cha, S., Croghan, I., Naessens, J.M., and Hanson, G.J. 2012. A randomized controlled trial of telemonitoring in older adults with multiple health issues to prevent hospitalizations and emergency department visits. Archives of Internal Medicine, Published Online First: 16

1

Use of personal call alarms among community-dwelling older people

Nyman, S. R., \& Victor,

C.

$\mathrm{R}$.

(2012).

Use

of

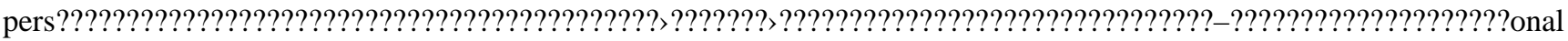
call alarms among community-

dwelling

older

people.

Ageing

\&

Society,

Published

online:

15

August,

DOI:

10.1017/S0144686X12000803.

(C)

Cambridge

University

Press

2012.

http://journals.cambridge.org/action/displayAbstract;jsessionid=CECAB498AA3794F4F65BFC3B843D6955.journals?fromPage= 
1

Use of personal call alarms among community-dwelling older people

Nyman, S. R., \& Victor,

C.

R.

(2012).

Use

of

pers?????????????????????????????????????????>??????+??????????????????????????????-????????????????????onal call alarms among community-

dwelling

older

people.

Ageing

\&

Society,

Published

online:

15

August,

DOI:

10.1017/S0144686X12000803.

(C)

Cambridge

University

Press

2012.

http:/journals.cambridge.org/action/displayAbstract;jsessionid=CECAB498AA3794F4F65BFC3B843D6955.journals?fromPage=

April, DOI: 10.1001/archinternmed.2012.256.

Taylor, R., Conway, L., Calderwood, L. and Lessof, C. 2003. Methodology. In Marmot, M., Banks J., Blundell R., Lessof C. and Nazroo J.(eds), Health, Wealth and Lifestyles of the Older Population in England: The 2002 English Longitudinal Study of Ageing. Institute for Fiscal Studies, London, 357-74.

Tinetti, M.E., Liu, W.-L. and Claus, E.B. 1993. Predictors and prognosis of inability to get up 
after falls among elderly persons. Journal of the American Medical Association, 269, 1, 6570.

Tinetti, M.E., Williams, T.F. and Mayewski, R. 1986. Fall risk index for elderly patients based on number of chronic disabilities. The American Journal of Medicine, 80, 3, 429-34.

Tinker, A. and Lansley, P. 2005. Introducing assistive technology into the existing homes of older people: Feasibility, acceptability, costs and outcomes. Journal of Telemedicine and

1

Use of personal call alarms among community-dwelling older people

Nyman, S. R., \& Victor,

C.

R.

(2012).

Use

of

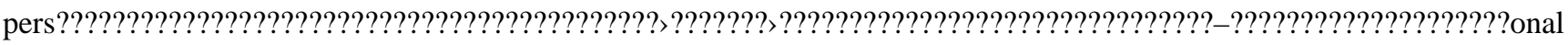
call alarms among community-

dwelling

older

people.

Ageing

\&

Society,

Published

online:

15

August,

DOI:

10.1017/S0144686X12000803.

(C)

Cambridge

University

Press

2012.

http://journals.cambridge.org/action/displayAbstract;jsessionid=CECAB498AA3794F4F65BFC3B843D6955.journals?fromPage= 
1

Use of personal call alarms among community-dwelling older people

Nyman, S. R., \& Victor,

C.

R.

(2012).

Use

of

pers?????????????????????????????????????????????????+?????????????????????????+????-????????????????????onal call alarms among community-

dwelling

older

people.

Ageing

\&

Society,

Published

online:

15

August,

DOI:

10.1017/S0144686X12000803.

(C)

Cambridge

University

Press

2012.

http:/journals.cambridge.org/action/displayAbstract;jsessionid=CECAB498AA3794F4F65BFC3B843D6955.journals?fromPage=

Telecare, 11, Suppl 1, 1-3.

Todd, C. J., Ballinger, C. \& Whitehead, S. 2007. A Global Report on Falls Prevention: Reviews of Socio-Demographic Factors Related to Falls and Environmental Interventions to Prevent Falls Amongst Older People Living in the Community. World Health Organization, Geneva.

Vedder, A. and Custers, B. 2009. Whose responsibility is it anyway? Dealing with the consequences of new technologies. In Sollie, P. and Düwell, M.(eds), Evaluating New 
Technologies: Methodological Problems for the Ethical Assessment of Technology Developments. Springer, Milton Keynes, UK, 21-34.

Victor, C.R. 2002. Using existing research and statistical data: Secondary data analysis. In Jamieson, A. and Victor C.R.(eds), Researching Ageing and Later Life: The Practice of Social Gerontology. Open University Press, Buckingham, 51-65.

Vlachantoni, A. 2010. The demographic characteristics and economic activity patterns of carers

1

Use of personal call alarms among community-dwelling older people

Nyman, S. R., \& Victor,

C.

$\mathrm{R}$.

(2012).

Use

of

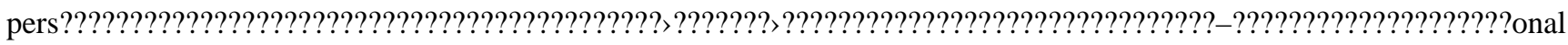
call alarms among community-

dwelling

older

people.

Ageing

\&

Society,

Published

online:

15

August,

DOI:

10.1017/S0144686X12000803.

(C)

Cambridge

University

Press

2012.

http://journals.cambridge.org/action/displayAbstract;jsessionid=CECAB498AA3794F4F65BFC3B843D6955.journals?fromPage= 
1

Use of personal call alarms among community-dwelling older people

Nyman, S. R., \& Victor,

C.

R.

(2012)

Use

of

pers?????????????????????????????????????????>?????????????????????????????????????-????????????????????onal call alarms among community-

dwelling

older

people.

Ageing

\&

Society,

Published

online:

15

August,

DOI:

10.1017/S0144686X12000803.

(C)

Cambridge

University

Press

2012.

http:/journals.cambridge.org/action/displayAbstract;jsessionid=CECAB498AA3794F4F65BFC3B843D6955.journals?fromPage=

over 50: Evidence from the English Longitudinal Study of Ageing. Population Trends, 141, 1, 54-76.

Wielandt, T. and Strong, J. 2000. Compliance with prescribed adaptive equipment: A literature review. British Journal of Occupational Therapy, 63, 2, 65-75.

Wild, D., Nayak, U.S. and Isaacs, B. 1981. How dangerous are falls in old people at home?

British Medical Journal, 282, 6260, 266-8. 
Yardley, L., Donovan-Hall, M., Francis, K. and Todd, C.J. 2006. Older people's views of advice about falls prevention: A qualitative study. Health Education Research, 21, 4, 508-17.

Address for correspondence:

Samuel R. Nyman, School of Design, Engineering \& Computing,

1

Use of personal call alarms among community-dwelling older people

Nyman, S. R., \& Victor,

C.

R.

(2012).

Use

of

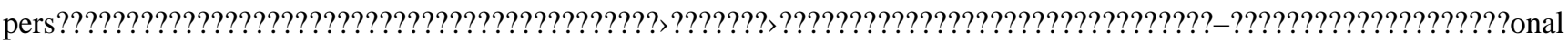
call alarms among community-

dwelling

older

people.

Ageing

\&

Society,

Published

online:

15

August,

DOI:

10.1017/S0144686X12000803.

(C)

Cambridge

University

Press

2012.

http://journals.cambridge.org/action/displayAbstract;jsessionid=CECAB498AA3794F4F65BFC3B843D6955.journals?fromPage= 
1

Use of personal call alarms among community-dwelling older people

Nyman, S. R., \& Victor,

C.

R.

(2012).

Use

of

pers?????????????????????????????????????????>?????????????????????????????????????-????????????????????onal call alarms among community-

dwelling

older

people.

Ageing

\&

Society,

Published

online:

15

August,

DOI:

10.1017/S0144686X12000803.

(C)

Cambridge

University

Press

2012.

http://journals.cambridge.org/action/displayAbstract;jsessionid=CECAB498AA3794F4F65BFC3B843D6955.journals?fromPage=

Bournemouth University, Poole House, Talbot Campus, Fern Barrow, Poole, Dorset BH12 5BB, United Kingdom

E-mail: snyman@bournemouth.ac.uk 
Table 1. Percentages (within columns) of self-reported use of a personal call alarm as a function of household composition

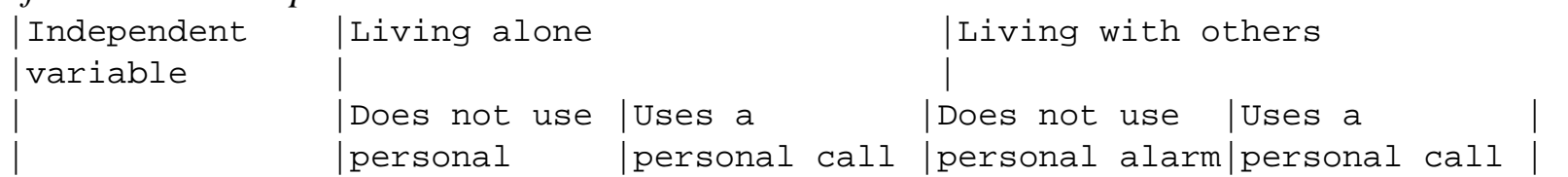

dwelling

older

people.

Ageing

\&

Society,

Published

online:

15

August,

DOI:

10.1017/S0144686X12000803.

(C)

Cambridge

University

Press

2012.

http:/journals.cambridge.org/action/displayAbstract;jsessionid=CECAB498AA3794F4F65BFC3B843D6955.journals?fromPage= 
1

Use of personal call alarms among community-dwelling older people

Nyman, S. R., \& Victor,

C.

R.

(2012)

Use

of

pers?????????????????????????????????????????>?????????????????????????????????????-????????????????????onal call alarms among community-

dwelling

older

people.

Ageing

\&

Society,

Published

online:

15

August,

DOI:

10.1017/S0144686X12000803.

(C)

Cambridge

University

Press

2012.

http:/journals.cambridge.org/action/displayAbstract;jsessionid=CECAB498AA3794F4F65BFC3B843D6955.journals?fromPage=

\begin{tabular}{|c|c|c|c|c|c|}
\hline & \begin{tabular}{|l} 
|alarm \\
$\mid \frac{\circ}{0}(\mathrm{n})$
\end{tabular} & $\begin{array}{l}\text { alarm } \\
\mid \circ \quad(n)\end{array}$ & $\div \quad(n)$ & \begin{tabular}{|l} 
|alarm \\
$\mid \% \quad(n)$
\end{tabular} & Total $\mathrm{n}$ \\
\hline \multicolumn{6}{|c|}{ Sociodemographics } \\
\hline Age & (1093) & |(147) & |(1791) & |(31) & $(3062)$ \\
\hline $65-74$ & |36\% & $18 \%$ & $\mid 58 \%$ & |39\% & 1463 \\
\hline $75-84$ & $42 \%$ & $37 \%$ & $36 \%$ & $42 \%$ & 1163 \\
\hline $85+$ & $22 \%$ & $45 \%$ & | 7\% & | $19 \%$ & 436 \\
\hline
\end{tabular}




$\left\{\begin{array}{cc}\mid \text { Gender } & \mid(1093) \\ \mid \text { Male } & \mid 25 \% \\ \text { Ethnicity } & \mid 75 \% \\ \mid \text { White } & \mid 98 \% \\ \mid \text { Not white } & \mid 2 \% \\ \text { Wealth } & \mid(1093) \\ \mid \text { High } & \mid 23 \%\end{array}\right.$

Use of personal call alarms among community-dwelling older people

Nyman, S. R., \& Victor,

C.

$\mathrm{R}$

(2012).

Use

of

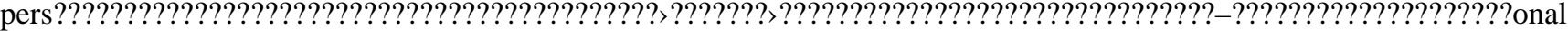
call alarms among community-

$\mid(147)$
$\mid 20 \%$
$\mid 80 \%$
$\mid(147)$
$\mid 99 \%$
$\mid 1 \%$
$\mid(147)$
$\mid 14 \%$

| (1791)

| $49 \%$

51\%

| (1791)

|98\%

2\%

| (1791)

| $42 \%$

$\mid(31)$
$\mid 39 \%$
$\mid 61 \%$
$\mid(31)$
$\mid 97 \%$
$\mid 3 \%$
$\left|\begin{array}{l}\mid 31) \\ \mid\end{array}\right|$
$\mid 29 \%$

| (3062)

1197

1865

|(3061)

2999

62

| (3062)

| 1029

\section{dwelling \\ older \\ people. \\ Ageing \\ \&}

Society,

Published

online:

15

August,

DOI:

10.1017/S0144686X12000803.

(c)

Cambridge

University

Press

2012.

http://journals.cambridge.org/action/displayAbstract;jsessionid=CECAB498AA3794F4F65BFC3B843D6955.journals?fromPage= 
1

Use of personal call alarms among community-dwelling older people

Nyman, S. R., \& Victor,

C.

R.

(2012)

Use

of

pers?????????????????????????????????????????>?????????????????????????????????????-????????????????????onal call alarms among community-

dwelling

older

people.

Ageing

\&

Society,

Published

online:

15

August,

DOI:

10.1017/S0144686X12000803.

(C)

Cambridge

University

Press

2012.

http:/journals.cambridge.org/action/displayAbstract;jsessionid=CECAB498AA3794F4F65BFC3B843D6955.journals?fromPage=

\begin{tabular}{|c|c|}
\hline Medium & $34 \%$ \\
\hline Low & $44 \%$ \\
\hline \multicolumn{2}{|l|}{ Health } \\
\hline Fallen in past & $(1067)$ \\
\hline 2 years & \\
\hline | No & $59 \%$ \\
\hline |Yes & | $41 \%$ \\
\hline
\end{tabular}

$\mid 24 \%$
$\mid 63 \%$
$\mid \begin{aligned} & (134) \\ & \mid 37 \% \\ & \mid 63 \%\end{aligned}$

$\mid \begin{aligned} & \mid 35 \% \\ & \mid 24 \%\end{aligned}$
$\mid \begin{aligned} & (1710) \\ & \mid 67 \% \\ & \mid 33 \%\end{aligned}$

$\mid \begin{aligned} & 16 \% \\ & 55 \%\end{aligned}$

1027

1006

|

(2937)

|(26)

|58\%

| $42 \%$ 


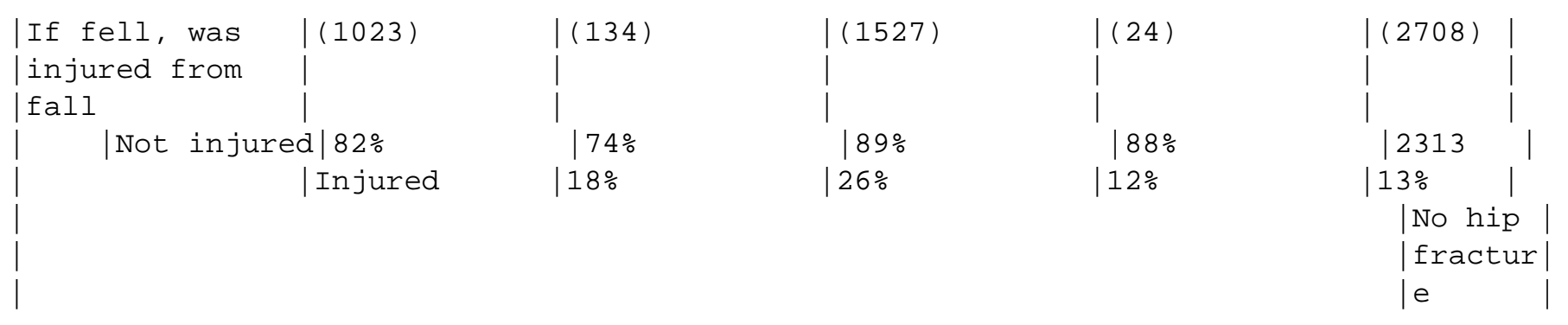

1

Use of personal call alarms among community-dwelling older people

Nyman, S. R., \& Victor,

C.

$\mathrm{R}$

(2012).

Use

of

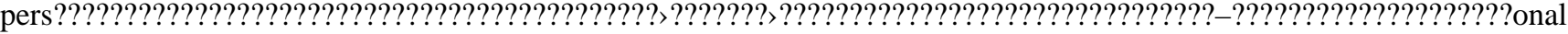
call alarms among community-

dwelling

older

people.

Ageing

\&

Society,

Published

online:

15

August,

DOI:

10.1017/S0144686X12000803.

(C)

Cambridge

University

Press

2012.

http://journals.cambridge.org/action/displayAbstract;jsessionid=CECAB498AA3794F4F65BFC3B843D6955.journals?fromPage= 
1

Use of personal call alarms among community-dwelling older people

Nyman, S. R., \& Victor,

C.

R.

(2012)

Use

of

pers?????????????????????????????????????????>?????????????????????????????????????-????????????????????onal call alarms among community-

dwelling

older

people.

Ageing

\&

Society,

Published

online:

15

August,

DOI:

10.1017/S0144686X12000803.

(C)

Cambridge

University

Press

2012.

http://journals.cambridge.org/action/displayAbstract;jsessionid=CECAB498AA3794F4F65BFC3B843D6955.journals?fromPage=

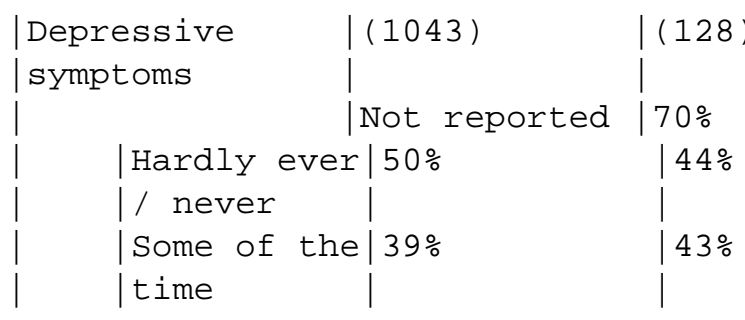

$\left\{\begin{array}{l}(1685) \\ 67 \% \\ \mid 71 \% \\ \mid 23 \%\end{array}\right.$

| (25)

(2881)

$86 \%$

$44 \%$

68\%

1549

$52 \%$ 


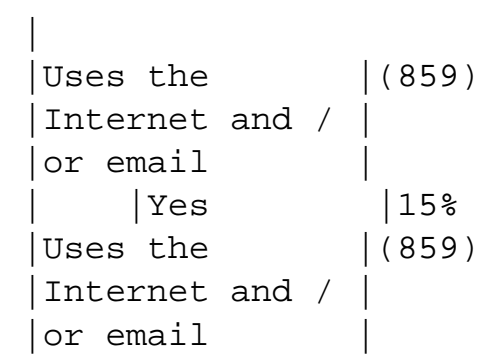

1

Use of personal call alarms among community-dwelling older people

Nyman, S. R., \& Victor,

C.

$\mathrm{R}$.

(2012).

Use

of

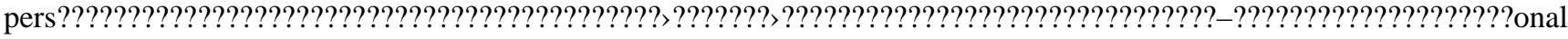
call alarms among community-

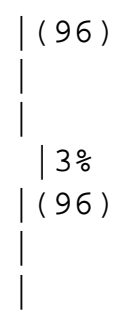

|(1509)

|(22)

|27\%

(1509)

| $18 \%$

(22)
| often

(2486)

540

(2486)

dwelling

older

people.

Ageing

\&

Society,

Published

online:

15

August,

DOI:

10.1017/S0144686X12000803.

(C)

Cambridge

University

Press

2012.

http://journals.cambridge.org/action/displayAbstract;jsessionid=CECAB498AA3794F4F65BFC3B843D6955.journals?fromPage= 
1

Use of personal call alarms among community-dwelling older people

Nyman, S. R., \& Victor,

C.

R.

(2012).

Use

of

pers?????????????????????????????????????????>?????????????????????????????????????-????????????????????onal call alarms among community-

dwelling

older

people.

Ageing

\&

Society,

Published

online:

15

August,

DOI:

10.1017/S0144686X12000803.

(C)

Cambridge

University

Press

2012.

http://journals.cambridge.org/action/displayAbstract;jsessionid=CECAB498AA3794F4F65BFC3B843D6955.journals?fromPage=

\begin{tabular}{|l|l|l|l|l|l}
$\mid$ Yes & $\mid 53 \%$ & $\mid 31 \%$ & $\mid 66 \%$ & $\mid 55 \%$ & $\mid 1483$ \\
$\mid$ No & $47 \%$ & $\mid 69 \%$ & $\mid 35 \%$ & $\mid 46 \%$ & $\mid 1003$
\end{tabular}


Table 2. Means and standard deviations of independent variables as a function of self-reported use of a personal call alarm and household composition

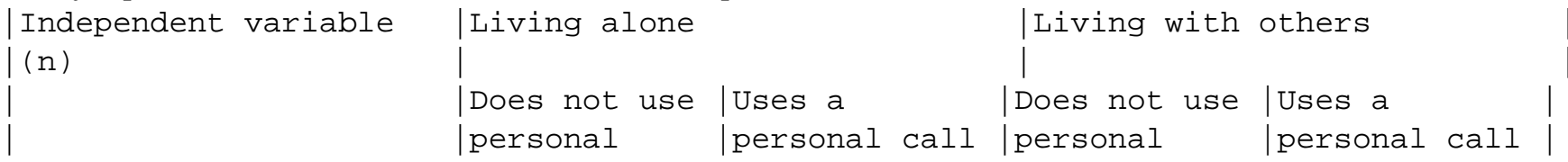

1

Use of personal call alarms among community-dwelling older people

Nyman, S. R., \& Victor,

C.

R.

(2012)

Use

of

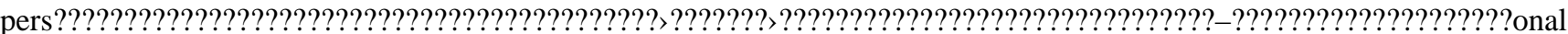
call alarms among community-

dwelling

older

people.

Ageing

\&

Society,

Published

online:

15

August,

DOI:

10.1017/S0144686X12000803.

(C)

Cambridge

University

Press

2012.

http://journals.cambridge.org/action/displayAbstract;jsessionid=CECAB498AA3794F4F65BFC3B843D6955.journals?fromPage= 
1

Use of personal call alarms among community-dwelling older people

Nyman, S. R., \& Victor,

C.

R.

(2012)

Use

of

pers?????????????????????????????????????????>??????+??????????????????????????????-????????????????????onal call alarms among community-

dwelling

older

people.

Ageing

\&

Society,

Published

online:

15

August,

DOI:

10.1017/S0144686X12000803.

(C)

Cambridge

University

Press

2012.

http:/journals.cambridge.org/action/displayAbstract;jsessionid=CECAB498AA3794F4F65BFC3B843D6955.journals?fromPage=

\begin{tabular}{|c|c|c|c|c|}
\hline & $\begin{array}{l}\text { alarm } \\
\mid \mathrm{M} \text { (SD) }\end{array}$ & $\begin{array}{l}\text { alarm } \\
\mid \mathrm{M} \text { (SD) }\end{array}$ & $\begin{array}{l}\text { alarm } \\
\mathrm{M}(\mathrm{SD})\end{array}$ & $\begin{array}{l}\text { alarm } \\
\text { M }(S D)\end{array}$ \\
\hline Sociodemographics & & & & \\
\hline Wealth (3062) & $\begin{array}{l}\mid £ 128,257.51 \\
(£ 158,466.81)\end{array}$ & $\begin{array}{l}\mid £ 74,019.89 \\
(£ 110,796.83)\end{array}$ & $\begin{array}{l}£ 221,739.17 \\
(£ 268,138.47)\end{array}$ & $\begin{array}{l}£ 157,243.42 \\
(£ 251,406.10)\end{array}$ \\
\hline $\begin{array}{l}\text { Health } \\
\text { Number of falls in the }\end{array}$ & $\mid 2.25 \quad(3.84)$ & $2.40 \quad(3.52)$ & $2.62(7.88)$ & $(2.42)$ \\
\hline
\end{tabular}




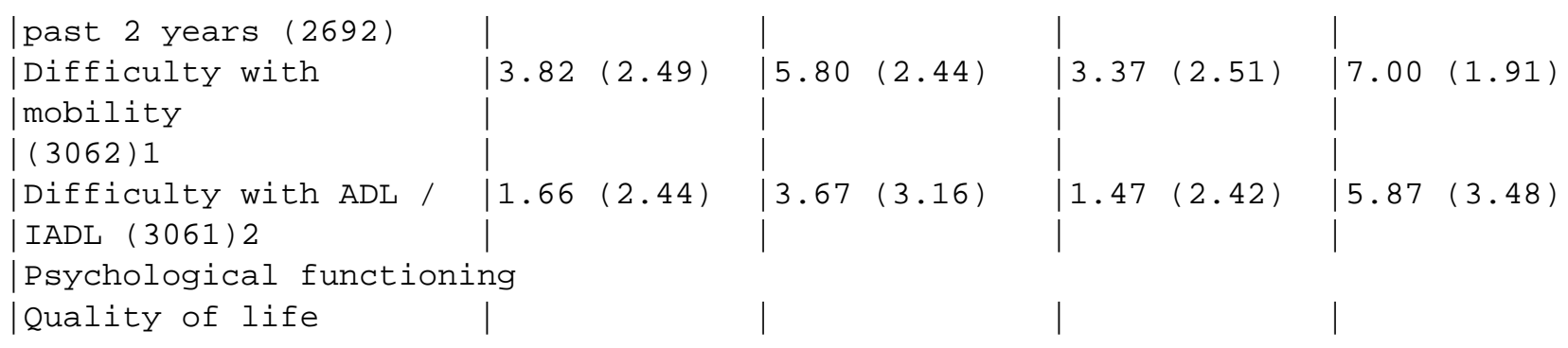

1

Use of personal call alarms among community-dwelling older people

Nyman, S. R., \& Victor,

C.

$\mathrm{R}$

(2012).

Use

of

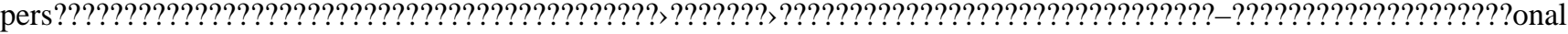
call alarms among community-

dwelling

older

people.

Ageing

\&

Society,

Published

online:

15

August,

DOI:

10.1017/S0144686X12000803.

(C)

Cambridge

University

Press

2012.

http://journals.cambridge.org/action/displayAbstract;jsessionid=CECAB498AA3794F4F65BFC3B843D6955.journals?fromPage= 
1

Use of personal call alarms among community-dwelling older people

Nyman, S. R., \& Victor,

C.

R.

(2012)

Use

of

pers?????????????????????????????????????????>??????+??????????????????????????????-????????????????????onal call alarms among community-

dwelling

older

people.

Ageing

\&

Society,

Published

online:

15

August,

DOI:

10.1017/S0144686X12000803.

(C)

Cambridge

University

Press

2012.

http:/journals.cambridge.org/action/displayAbstract;jsessionid=CECAB498AA3794F4F65BFC3B843D6955.journals?fromPage=

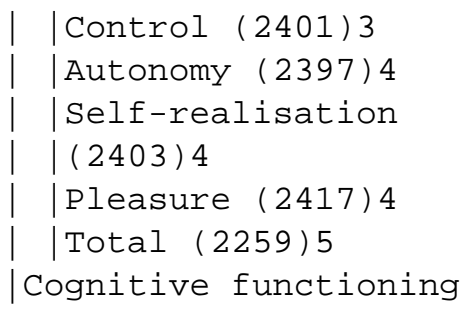

\begin{tabular}{|c|c|c|c|}
\hline$(2.48)$ & $(2.41)$ & $(2.40)$ & $4.60 \quad(2.19)$ \\
\hline $10.37 \quad(2.55)$ & $(2.21)$ & $(2.66)$ & $(2.18)$ \\
\hline $8.32 \quad(3.17)$ & $(3.17)$ & $9.29(2.93)$ & $6.00 \quad(3.61)$ \\
\hline$(2.43)$ & $(2.32)$ & $(2.08)$ & $(2.28)$ \\
\hline $37.77 \quad(8.43)$ & $35.11(7.76)$ & $39.06 \quad(8.07)$ & 32.11 \\
\hline$(1.45)$ & $(1.25)$ & $(1.41)$ & $(1.80)$ \\
\hline
\end{tabular}


Notes: 1) Possible scores range 1-10, with higher scores indicating greater difficulty with mobility. 2) Possible scores range 1-13, with higher scores indicating greater difficulty with activities of daily living (ADL) or instrumental activities of daily living (IADL). 3) CASP-19 subscale; possible scores range 0-12, with higher scores indicating better quality of life. 4) CASP-

1

Use of personal call alarms among community-dwelling older people

Nyman, S. R., \& Victor,

C.

$\mathrm{R}$

(2012).

Use

of

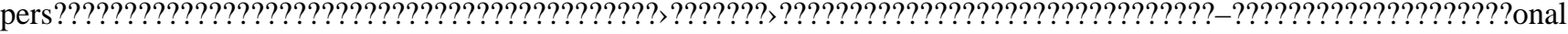
call alarms among community-

dwelling

older

people.

Ageing

\&

Society,

Published

online:

15

August,

DOI:

10.1017/S0144686X12000803.

(c)

Cambridge

University

Press

2012.

http://journals.cambridge.org/action/displayAbstract;jsessionid=CECAB498AA3794F4F65BFC3B843D6955.journals?fromPage= 
1

Use of personal call alarms among community-dwelling older people

Nyman, S. R., \& Victor,

C.

R.

(2012)

Use

of

pers?????????????????????????????????????????>?????????????????????????????????????-????????????????????onal call alarms among community-

dwelling

older

people.

Ageing

\&

Society,

Published

online:

15

August,

DOI:

10.1017/S0144686X12000803.

(C)

Cambridge

University

Press

2012.

http:/journals.cambridge.org/action/displayAbstract;jsessionid=CECAB498AA3794F4F65BFC3B843D6955.journals?fromPage=

19 subscale; possible scores range 0-15, with higher scores indicating better quality of life. 5)

CASP-19 summed total; possible scores range 0-57, with higher scores indicating better quality of life. 6) Possible scores range 5-10, with higher scores indicating better cognitive functioning. 
Table 3: Multivariate predictors of self-reported personal call alarm use as a function of household composition

\begin{tabular}{|l|l|} 
& $\mid$ Multivariate OR (95\% CI) for more likely to \\
$\mid$ Independent & $\mid$ Living alone $(\mathrm{n}=\mid$ Living with others $(\mathrm{n}=$ \\
$\mid$ variables & $\mid$ 810)1
\end{tabular}

1

Use of personal call alarms among community-dwelling older people

Nyman, S. R., \& Victor,

C.

R.

(2012)

Use

of

pers??????????????????????????????????????????????+???????????????????????+????-???????????????????0nal call alarms among community-

dwelling

older

people.

Ageing

\&

Society,

Published

online:

15

August,

DOI:

10.1017/S0144686X12000803.

(C)

Cambridge

University

Press

2012.

http:/journals.cambridge.org/action/displayAbstract;jsessionid=CECAB498AA3794F4F65BFC3B843D6955.journals?fromPage= 
1

Use of personal call alarms among community-dwelling older people

Nyman, S. R., \& Victor,

C.

R.

(2012)

Use

of

pers?????????????????????????????????????????>?????????????????????????????????????-????????????????????onal call alarms among community-

dwelling

older

people.

Ageing

\&

Society,

Published

online:

15

August,

DOI:

10.1017/S0144686X12000803.

(C)

Cambridge

University

Press

2012.

http:/journals.cambridge.org/action/displayAbstract;jsessionid=CECAB498AA3794F4F65BFC3B843D6955.journals?fromPage=

| Sociodemographics
|Age
$\mid \begin{gathered}\mid 65-74 \\ \mid 75-84 \\ \mid 85+\end{gathered}$
$\mid$ Wealth
$\mid$ High

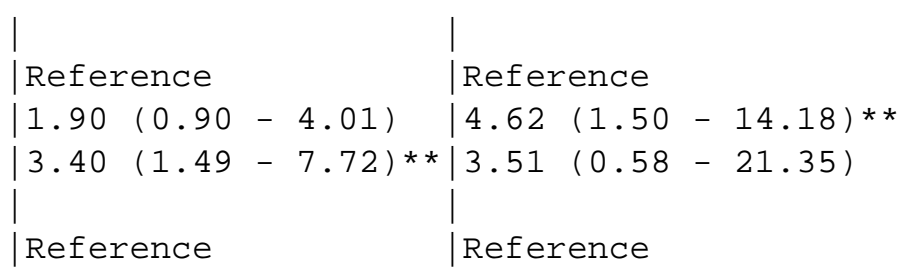



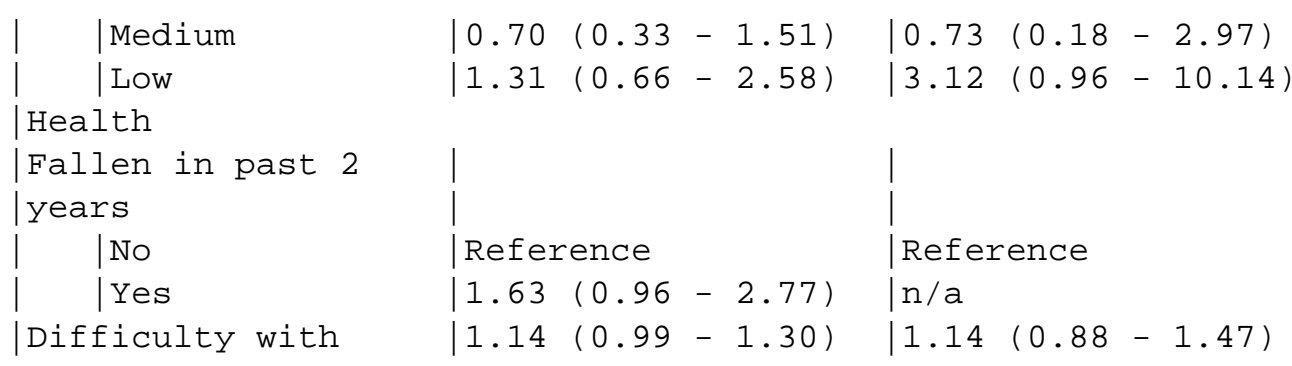

1

Use of personal call alarms among community-dwelling older people

Nyman, S. R., \& Victor,

C.

R.

(2012).

Use

of

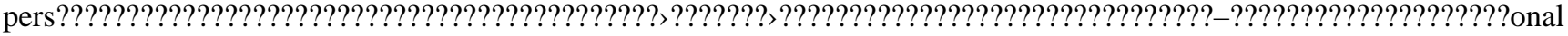
call alarms among community-

dwelling

older

people.

Ageing

\&

Society,

Published

online:

15

August,

DOI:

10.1017/S0144686X12000803.

(C)

Cambridge

University

Press

2012.

http://journals.cambridge.org/action/displayAbstract;jsessionid=CECAB498AA3794F4F65BFC3B843D6955.journals?fromPage= 
1

Use of personal call alarms among community-dwelling older people

Nyman, S. R., \& Victor,

C.

R.

(2012)

Use

of

pers?????????????????????????????????????????>?????????????????????????????????????-????????????????????onal call alarms among community-

dwelling

older

people.

Ageing

\&

Society,

Published

online:

15

August,

DOI:

10.1017/S0144686X12000803.

(C)

Cambridge

University

Press

2012.

http:/journals.cambridge.org/action/displayAbstract;jsessionid=CECAB498AA3794F4F65BFC3B843D6955.journals?fromPage=

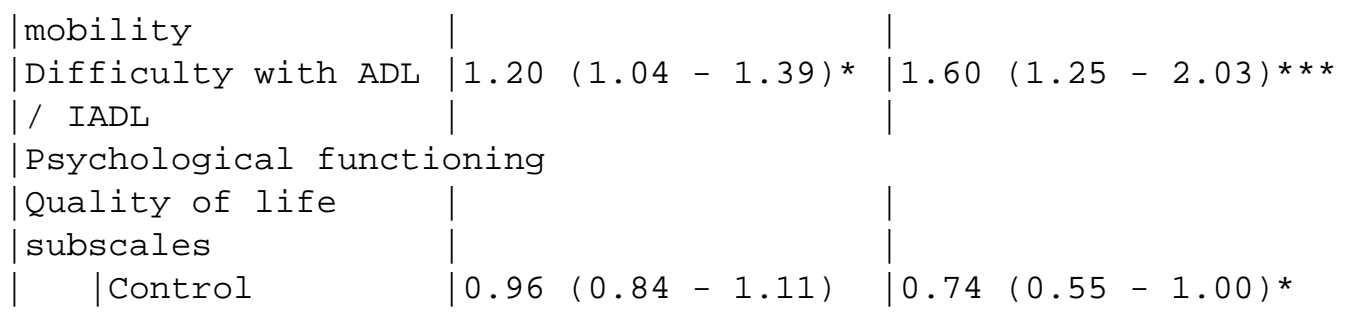




\begin{tabular}{|c|c|c|}
\hline Autonomy & $1.03(0.90-1.18)$ & $1.11(0.86-1.42)$ \\
\hline Self-realisation & $1.01(0.91-1.12)$ & $1.01(0.83-1.22)$ \\
\hline \multicolumn{3}{|l|}{ Feels isolated } \\
\hline $\begin{array}{l}\text { |Hardly ever / } \\
\text { never }\end{array}$ & Reference & Reference \\
\hline Some of the time & $\mathrm{n} / \mathrm{a}$ & $1.11(0.38-3.26)$ \\
\hline Often & $\mathrm{n} / \mathrm{a}$ & $0.23(0.02-2.38)$ \\
\hline Cognitive & $(0.75-1.17)$ & $1.35(0.93-1.95)$ \\
\hline
\end{tabular}

Use of personal call alarms among community-dwelling older people

Nyman, S. R., \& Victor,

C.

$\mathrm{R}$

(2012).

Use

of

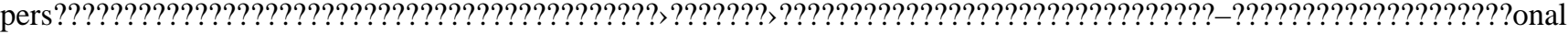
call alarms among community-

dwelling

older

people.

Ageing

\&

Society,

Published

online:

15

August,

DOI:

10.1017/S0144686X12000803.

(C)

Cambridge

University

Press

2012.

http://journals.cambridge.org/action/displayAbstract;jsessionid=CECAB498AA3794F4F65BFC3B843D6955.journals?fromPage= 
1

Use of personal call alarms among community-dwelling older people

Nyman, S. R., \& Victor,

C.

R.

(2012)

Use

of

pers?????????????????????????????????????????>???????+????????????????????????+????-????????????????????onal call alarms among community-

dwelling

older

people.

Ageing

\&

Society,

Published

online:

15

August,

DOI:

10.1017/S0144686X12000803.

(C)

Cambridge

University

Press

2012.

http://journals.cambridge.org/action/displayAbstract;jsessionid=CECAB498AA3794F4F65BFC3B843D6955.journals?fromPage=

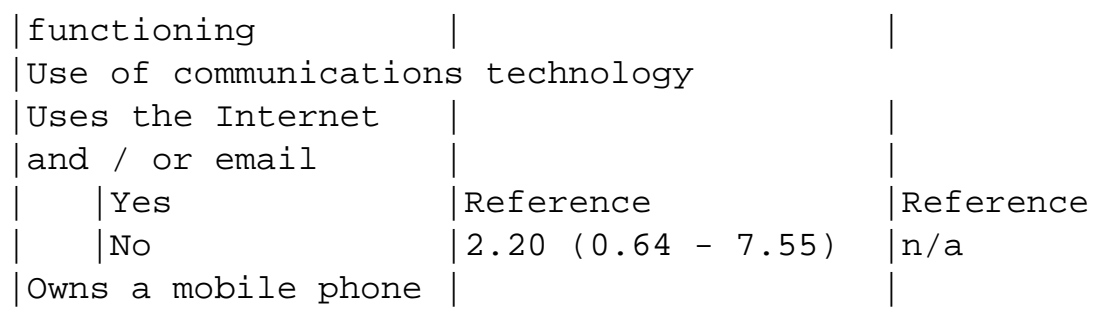




\begin{tabular}{l|ll}
$\mid$ Yes & $\mid$ Reference & $\mid$ Reference \\
No & $\mid 1.19(0.67-2.14)$ & $\mid$ n/a
\end{tabular}

Notes: Results from multivariate logistic regression with only the significant bivariate relationships entered. $\mathrm{OR}=$ odds ratio. $\mathrm{CI}=$ confidence interval. $\mathrm{ADL}=$ activities of daily living. $\mathrm{IADL}=$ Instrumental activities of daily living. Significance levels: $*=p<0.05 . * *=p<0.01$.

1

Use of personal call alarms among community-dwelling older people

Nyman, S. R., \& Victor,

C.

$\mathrm{R}$.

(2012).

Use

of

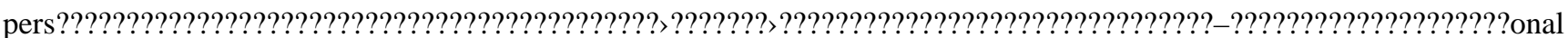
call alarms among community-

dwelling

older

people.

Ageing

\&

Society,

Published

online:

15

August,

DOI:

10.1017/S0144686X12000803.

(C)

Cambridge

University

Press

2012.

http://journals.cambridge.org/action/displayAbstract;jsessionid=CECAB498AA3794F4F65BFC3B843D6955.journals?fromPage= 
1

Use of personal call alarms among community-dwelling older people

Nyman, S. R., \& Victor,

C.

R.

(2012)

Use

of

pers?????????????????????????????????????????>??????+??????????????????????????????-????????????????????onal call alarms among community-

dwelling

older

people.

Ageing

\&

Society,

Published

online:

15

August,

DOI:

10.1017/S0144686X12000803.

(C)

Cambridge

University

Press

2012.

http:/journals.cambridge.org/action/displayAbstract;jsessionid=CECAB498AA3794F4F65BFC3B843D6955.journals?fromPage=

$* * *=p<0.001 .1) R^{2}=.093$ (Cox \& Snell), .203 (Nagelkerke). Model ?2(13) $=79.00, p<.001$.

2) $R^{2}=.047$ (Cox \& Snell), .332 (Nagelkerke). Model $?^{2}(12)=65.90, p<.001$. 